National

Academy

of

Sciences

National Research Council

D

NUCLEAR SCIENCE SERIES

NAS-NS

3021

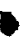

The Radiochemistry of Technetium 


\section{DISCLAIMER}

This report was prepared as an account of work sponsored by an agency of the United States Government. Neither the United States Government nor any agency Thereof, nor any of their employees, makes any warranty, express or implied, or assumes any legal liability or responsibility for the accuracy, completeness, or usefulness of any information, apparatus, product, or process disclosed, or represents that its use would not infringe privately owned rights. Reference herein to any specific commercial product, process, or service by trade name, trademark, manufacturer, or otherwise does not necessarily constitute or imply its endorsement, recommendation, or favoring by the United States Government or any agency thereof. The views and opinions of authors expressed herein do not necessarily state or reflect those of the United States Government or any agency thereof. 


\section{DISCLAIMER}

Portions of this document may be illegible in electronic image products. Images are produced from the best available original document. 


\title{
The Radiochemistry of Technetium
}

BY EDWARD ANDERS

\author{
Enrico Fermi Institute \\ and \\ Department of Chemistry \\ University of Chicago \\ Chicago 37, Illinots
}

November 1960

Subcommittee on Radiochemistry

National Academy of Bciences - National Research Councll 
Available as NAS-NS-3021 for $\$ 9.50$ from

National Technical Information Service

U. S. Department of Commerce

Springfield, Virginia 22161

Printed in the United States of America

USDOE Office of Scientific and Technical Information, Oak Ridge, Tennessee

1960: latest printing May 1985 


\section{FOREWORD}

The Subcomittee on Radiochemistry is one of a number of subcommittees work1ng under the Committee on Nuclear sclence within the National Academy of Sc1ences - National Research Counc1l. Its members represent government, Industrial, and university laboratories in the areas of nuclear chemistry and analytical chemistry

The Subcommittee has concerned 1tself w1th those areas of nuclear sclence which involve the chemlst, such as the collection and distribution of radiochemical procedures, the establishment of specifications for radiochemically pure reagents, avallablilty of cyclotron time for service irradiations, the place of radlochemistry in the undergraduate college program, etc.

Th1s serles of monographs has grown out of the need for up-to-date compilations of radiochemical information and procedures. The subcomnlttee has endeavored to present a serles which w11l be of maximum use to the working scientist and which contains the latest avallable information. Each monograph collects in one volume the pertinent information required for radiochemical work with an individual element or a group of closely releted elements.

An expert in the radiochemlstry of the particular element has written the monograph, following a standard format developed by the Subcomittee. The Atomic Energy Comniseion has oponsored the printing of the series.

The Subcommittee is confldent these publications w11l be useful not only to the radiochemist but also to the research worker in other flelds such as physics, blochemistry or medicine who wishes to use radiochemical technlques to solve a specific problem. 


\section{INTRODUCTION}

Th1s volume which deals with the radiochemistry of technetium is one of a serles of monographs on radiochemistry of the elements. There is included a review of the nuclear and chemlcal features of particular interest to the radiochemist, a discussion of problems of dissolution of a sample and counting techniques, and finally, a collection of radiochemical procedures for the element as found in the i1terature.

The series of monographs will cover all elements for which radiochemical procedures are pertinent. Plans include revision of the monograph periodically as new techniques and procedures warrant. The reader 18 therefore encouraged to call to the attention of the author any published or unpublished material on the radiochemistry of technetium which might be included in a revised version of the monograph. 


\section{CONTENTS}

I. General Reviews of the Inorganic, Analytical and Radiochemistry of Technetium

II. Table of Isotopes of Technetium

III. Review of those Features of Technetium Chemistry of Chlef Interest to Radiochemists

1. General Remarks 3

2. Metallic technetlum 3

3. Solution chemistry of technetium 4

a. Oxidation State $+7 \quad 4$

b. Oxidation State +4 8

c. Oxidation States +6 and $+5 \quad 9$

d. Oxidation state +3 and unidentified lower states

4. Volat1lization Methods 12

5. Extraction of technetium into organic solvents 15

6. Chromatographic behavior of technet1um 17

7. Electrochemical behavior 20

IV. Dissolution of Samples Contalning Compounds of Technetium

V. Counting Techniques for Use with Isotopes of Technetium

1. Counting 22

2. Chemical yield determination 23

VI. Collection of Detalled Radiochemlcal Procedures for Technetium 


\title{
The Radiochemistry of Technetium
}

\author{
BDWARD ANDERS \\ Enrico Fermi Institute \\ and \\ Department of Chemistry, University of Chicago \\ Chicrgo 37, Dlinole \\ November 1960
}

I. General Reviews of the Inorganlc, Analytical and Radiochemistry of Technetium.

Gmelin's Handbuch der anorganischen Chemie, System$\mathrm{Nr}$. 69/70, Masurium. Rhenium, 8th Ed. (Verlag

Chemle, Berlin, $154 \mathrm{pp} ., 1955$ ).

Tribalat, S., Rhénium et Technétium, (Gauthiervillars, Paris, 172 pp., 1957).

Hackney, J. C., Technet1um, Element 43, J. Chem. Educ. 28, 186 (1951).

Segrè, E., I nuov1 element1 chimic1, 21-30, Conf. Donegan1 (Academia Nazionale del Lincel, Rome, Italy, 118 pp., 1953.

Boyd, G. E., Discovery, Production and Properties of the Synthetic Elements Tc and Pm, J. Chem. Educ., 36, 3 (1959).

Anders, E., Technetium and Astatine Chemistry, Ann. Rev. Nucl. Sc1. 9, 203-220 (1959). 
II. Table of Isotopes of Technetium

\begin{tabular}{|c|c|c|c|}
\hline Isotope & Half-11fe & Type of decay & Method of preparation \\
\hline $\mathrm{Tc}^{92}$ & $4.3 \mathrm{~m}$ & $\beta^{+}, \mathrm{EC}$ & $\mu_{0}^{92}(p, n)$ \\
\hline $\mathrm{Tc}^{93 \mathrm{~m}}$ & $43.5 \mathrm{~m}$ & IT $280 \%$, EC 20\% & Mo $^{92}(d, n)$ \\
\hline $\mathrm{Tc}^{93}$ & $2.75 \mathrm{~h}$ & BC $88 \%, \beta^{+} 12 \%$ & Mo $^{92}(d, n)$ \\
\hline $\mathrm{Tc}^{94}$ & $53 m$ & $\beta^{+} \sim 75 \%$, EC $\sim 25 \%$ & $\mathrm{Mo}^{94}(p, n)$ \\
\hline $\mathrm{Tc}^{95 \mathrm{~m}}$ & $60 d$ & EC $96+\phi$, IT $\sim 3 \%, \beta^{+} \sim 0.4 \phi$ & $M_{0}^{95}(p, n)$ \\
\hline $\mathrm{Tc}^{95}$ & $2 \mathrm{C} . \mathrm{Oh}$ & $\mathbf{E C}$ & $\mathrm{Mo}^{95}(p, n)$ \\
\hline $\mathrm{Tc}^{96 \mathrm{~m}}$ & $51.5 \mathrm{~m}$ & IT & $M_{0}^{96}(p, n)$ \\
\hline $\operatorname{Ic}^{96}$ & $4.20 d$ & EC & $\mathrm{Mo}^{96}(p, n)$ \\
\hline $\mathrm{Tc}^{97 \mathrm{~m}}$ & $91 d$ & IT & Mo $^{97}(p, n)$ \\
\hline $\mathrm{Tc}^{97}$ & $2.6 \times 10^{6} y$ & $\mathbf{E C}$ & daughter $\mathrm{Ru} 97$ \\
\hline $\mathrm{Tc}^{98}$ & $1.5 \times 10^{6} y$ & $\mathrm{~B}^{-}$ & Mo $^{98}(p, n)$ \\
\hline $\mathrm{Tc}^{99 \mathrm{~m}}$ & $6.04 h$ & IT & deughter Mo99 \\
\hline$T c^{99}$ & $2.12 \times 10^{5} y$ & $\beta^{-}$, no $\gamma$ & daughter $\mathrm{Tc}^{99 \mathrm{~m}} ;$ f1s810 \\
\hline $\mathrm{Tc}^{100}$ & 15.88 & $\beta^{-}$ & $\mathrm{Mo}^{100}(p, n)$ \\
\hline $\mathrm{Tc}^{101}$ & $14.0 \mathrm{~m}$ & $\beta^{-}$ & $\mathrm{Mo}^{100}(d, n)$ \\
\hline $\mathrm{Tc}^{102}$ & 58 & $B^{-}$ & rission \\
\hline $\mathrm{Tc}^{102}$ & $4.5 \mathrm{~m}$ & $\beta^{-}$ & f1ssion \\
\hline $\mathrm{Tc}^{103}$ & $1.2 \mathrm{~m}$ & $\mathrm{~B}^{-}$ & Plssion \\
\hline $\mathrm{Tc}^{104}$ & $18 m$ & $\beta^{-}$ & fission \\
\hline $\mathrm{Tc}^{105}$ & $10 \mathrm{~m}$ & $\beta^{-}$ & fission \\
\hline $\mathrm{Tc}^{107}$ & $<2.5 \mathrm{~m}$ & $\beta^{-}$ & f1ssion \\
\hline
\end{tabular}

See "Table of Isotopes" by D. Strominger, J. Hollander, and $Q$. Seaborg, Reviews of Modern Phys1cs 30, 585-904 (1958), for more complete information and for references to the original 11terature. 
III. REVIEW OF THOSE FEATURES OF TECHNETIUM CHEMISTRY OF CHIEF INTEREST TO RADIOCHEMISTS

1. General Remarks

In many respects, the analytical behavior of TC is similar to that of Re. Both form stable $\mathrm{XO}_{4}^{-}$anions that give insoluble salts with large cations; both form volatile heptoxides; and both form ac1d-insoluble heptasulfides. However, there are subtle differences between the two elements that can cause them to behave very differently under certain conditions. The vapor pressure of $\mathrm{Tc}_{2} \mathrm{O}_{7}{ }^{1}$ is much higher than that of $\operatorname{Re}_{2}{ }_{7}$ at low temperatures $\left(e .8 \cdot 10^{-1} \mathrm{~mm}\right.$ at $100^{\circ} \mathrm{C}$, compared to $\sim 3 \times 10^{-5} \mathrm{~mm}$ for $\operatorname{Re}_{2} \mathrm{O}_{7}$ ). In contrast to rhenium, technetium (VII) is therefore easily lost upon evaporation of acid solutions unless a reducing agent is present or the evaporation is conducted at a low temperature. Ignorance of these factors has led to a multitude of conflicting statements concerning the volatility of technetium.

Another Important property of Tc(VII) 1s 1ts relatively greater ease of reduction, and the slowness of some of the intermediate steps in the reduction process. Pertechnetate ion is reduced to a lower oxidation state by hydrochloric ac1d, thlocyanate $10 n^{2}$, organic 1mpurities present in tetraphenylarsonium chloride ${ }^{3}$, anion exchange resin ${ }^{4}$, and some organic solvents. Yet the complete reduction to TC(IV) 18 slow, and by analogy with shentum 5 , a multiplic1ty of reaction products may be expected. Unless precautions are taken to malntain technetium in the appropriate oxidation state, erratic results will be obtalned.

\section{Metali1c technetium}

Technetium metal can be prepared by reduction of the 
sulfide with hydrogen at $1100^{\circ} \mathrm{c}^{6,7}$. A purer product is obtained by hydrogen reduction of ammonium pertechnetate at $500-600^{\circ} \mathrm{C}^{8}$, or by electrodeposition from $2 \mathrm{~N} \mathrm{H}_{2} \mathrm{SO}_{4}$ in the presence of traces of fluoride ${ }^{9}$. The metal has a density of 11.49 and melts at $2140 \pm 20^{\circ} \mathrm{C}$ under atmospheric pressure ${ }^{10}$.

Technetium metal dissolves in nitric acid, aqua regia, and hot, concentrated sulfuric acid. It is insoluble in hydrochloric acid and, in contrast to rhenlum, in neutral or alkaline hydrogen peroxide 7,8 . It tarnishes slowly in mo1st $21 r$.

\section{Solution chemistry of technetium}

By analogy with rhenlum, all oxidation states between -1 and +7 may be expected for technetium. Of these, the +7 is the most important, though the $+4,+5$ and +6 states may also be of interest in some analytical applications.

\section{a. Oxidation State +7}

Ammonium pertechnetate. The most common compound of $\mathrm{Tc}$ (VII) is ammonium pertechnetate, $\mathrm{NH}_{4} \mathrm{TcO}_{4}$, a white, water soluble salt. It is usually obtained by dissolving technetium heptasulfide in ammonia and hydrogen peroxide. When prepared in this manner, it is often heavily contaminated with $\left(\mathrm{NH}_{4}\right)_{2} \mathrm{SO}_{4}$ and $\mathrm{NH}_{4} \mathrm{NO}_{2}$, and decomposes to $\mathrm{TcO}_{2}$ on heating 6,11 , but a somewhat purer product has apparently been sublimed in vacuo without decomposition ${ }^{12}$.

Technetium heptoxide and pertechnetic ac1d. The yeliow, crystalline oxlde has been prepared by burning the metal in oxygen at $400-600^{\circ} \mathrm{C}{ }^{13}$. It melts at $119.5^{\circ} \mathrm{C}$ and bolls at $311^{\circ} \mathrm{C}$. Technetium heptoxide dissolves in water to give a colorless solution of $\mathrm{HTCO}_{4}$. The vapor pressures of both the 
acid and the heptoxide are rather high even at low temperatures $^{l}$, and while this is a handicap in some respects, it also makes possible a number of chemical separations.

The coprecipitation behavior of pertechnetate ion has been 1nvestigated in some deta1l. It forms slightly soluble salts with large cations, e.g., $\mathrm{Tl}^{+}, \mathrm{Ag}^{+}, \mathrm{Cs}^{+}, \mathrm{nitron}$, and $\left(\mathrm{C}_{6} \mathrm{H}_{5}\right)_{4} \mathrm{As}^{+}$. At $0^{\circ} \mathrm{C}$, precipitation with the last-mentioned reagent is feasible at concentrations as low as $5 \mathrm{mg} \mathrm{Tc} / \mathrm{l} 14$. At lower concentrations, any of the $\mathrm{XY}_{4}^{-}$anions may be used as carriers: e.g., $\mathrm{ReO}_{4}^{-}, \mathrm{ClO}_{4}^{-}, \mathrm{IO}_{4}^{-}$, and $\mathrm{BF}_{4}^{-} 15,16,17$. In acid solutions, molybdenum also precipitates, hit in basic solutions, 1 does not interfere. Decontamination from other fission products is excellent: a single-step $B$ decontamination factor of $10^{5}$ has been reported. The principal remaining contaminants are $\mathrm{Zr}, \mathrm{Nb}$, and $\mathrm{Ru}{ }^{17}$. Coprecipitation with $\left(\mathrm{C}_{6} \mathrm{H}_{5}\right)_{4} \mathrm{AsReO}_{4}$ 1s probably the fastest known separation method for Tc; when milking $5 \mathrm{sec} . \mathrm{Tc}^{102}$ from $11.5 \mathrm{~min}$. Mol 102 , Flegenhelmer et al ${ }^{18}$ were ahle to prec1pitate and filter the sample in 5-6 seconds.

Removal of the technetium from the organic precipitate may be accomplished by wet combustion, by electrolysis in concentrated $\mathrm{H}_{2} \mathrm{SO}_{4}$, or by passing an alcohol solution of the precipltate through a strong-base anion exchanger in the chloride form. The organic cation passes through the exchanger, while the pertechnetate 18 adsorbed and may be subsequently eluted by $\mathrm{HClO}_{4} 8,29$.

Pertechnetate does not coprecipitate w1th manganese and ruthenlum dioxides, zirconium hydroxide, tantal1c and niob1c ac1ds, the 8-hydroxyquinolate and benzidinate of molybdenum $(V I)^{20,21}$, s1lver molybdate 22 , lead molybdate, ferric hydrox$1 d e$, and $a$-benzoln oxime molybdate ${ }^{23}$. 
Technetium heptasulfide. This compound can be prepared by precipitation from solutions 2 to $4 \underline{\mathrm{N}}$ in $\mathrm{HCl}$ or $\mathrm{H}_{2} \mathrm{SO}_{4}$ by means of hydrogen sulfide 7,11 . As little as $3 \mathrm{mg} / \mathrm{l}$ of technetium may be precipitated by $\mathrm{H}_{2} \mathrm{~S}$ from $4 \mathrm{M}_{2} \mathrm{SO}_{4} 11,23$. The precipitation is sluggish and incomplete under some conditions, particularly if the technetium is not all in the +7 state 7,15 . Many of the precautions required in the precipitation of rhentum $24,25,26$ are equally applicable to technetium.

At trace levels, the sulfides of Pt, Re, Cu, Mn, and many other elements may be used as carriers. Detalled studies on the optimum conditions for coprecipitation have been made $20,21,23,27 . \mathrm{Cu}^{+}$is a very effective carrier at acid concentrations of $0.2-3 N$, and offers the advantage of being easily separable from $\mathrm{TCO}_{4}{ }^{-}$. The sulfide is dissolved In ammoniacal hydrogen peroxide, the peroxide destroyed by bolling, and the copper removed by passing the solution through a cation exchanger (e.8. Dowex 50) in the ammonium form ${ }^{33}$. The resulting pertechnetate solution is still contaminated with ammonium sulfate and nitrite. If material of low solids content is required, the technetium may be electrodeposited as the dioxide on a platinum cathode, and redissolved in a minimum amount of ammoniacal hydrogen peroxide 23 Thloacetamide ${ }^{28}$ or sodium thiosulfate 15,26 may be used to advantage instead of hydrogen sulfide (F1g. 1).

Many other elements in this region of the periodic table precipitate under the same conditions, so that the method is more useful for purposes of concentration than separation. However, the lower oxidation states of TC do not precipitate with $\mathrm{H}_{2} \mathrm{~S}$ in strongly acid solutions, and one may therefore separate TC from Re by conducting the precipi- 


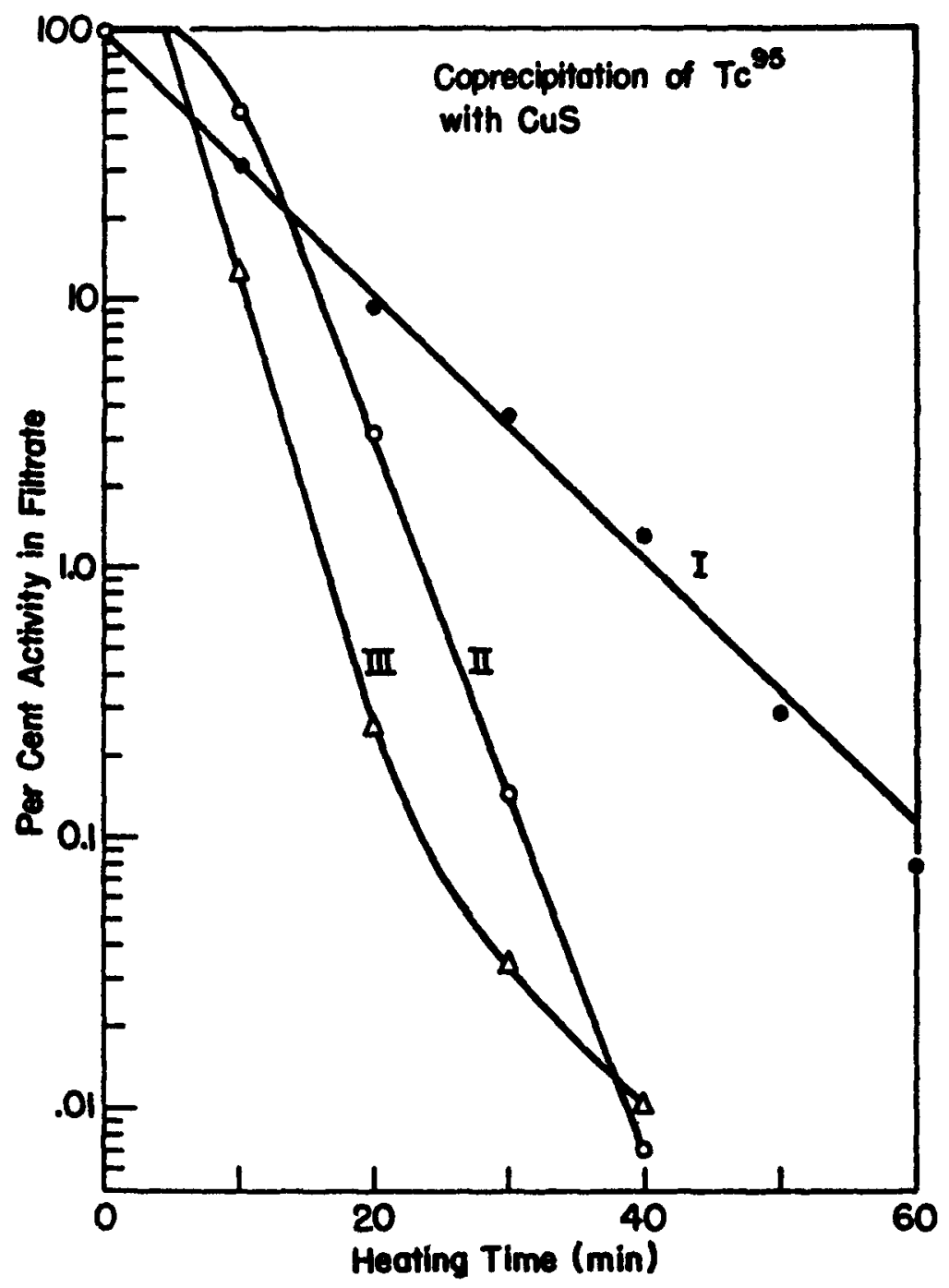

F1g. 1.

Coprecipitation of $\mathrm{TcO}_{4}{ }^{-}$with oopper aulide.

Curve I 2 mg Cu${ }^{++} / 40$ al $0.2 \mathrm{MC} \mathrm{HClO}_{4}$, preclpltated with $\mathrm{H}_{2} \mathrm{~s}$.

Curve II $2 \mathrm{mg} \mathrm{Cu}+40 \mathrm{ml} 0.2 \mathrm{M} \mathrm{HC1O}_{4}$, pptd. W. thionestanide $(0.5 \%)$.

Curve III 1 ig $\mathrm{Cu}^{++} / 20 \mathrm{ml} 0.5 \mathrm{M} \mathrm{H}_{2} \mathrm{SO}_{4}$, pptd. W. thloacetan1de $(0.5 \%)$.

Solutions inftially at room temp.; heated to $90-100^{\circ} \mathrm{C}$ within $5-7 \mathrm{~min}$. 
tation in a medium that reduces Tc(VII), e.g. 9-ION HCl 15,23,29. The separation is not sharp, however, since several percent of technetium coprecipitate with the rhenium, and measurable amounts of rhenium remain in solution.

b. Oxidation State +4

Technetium (VII) is reduced to lower oxidation states by many reducing agents. In dilute sulfuric acid medium, hydrazine, hydroxylamine, ascorbic acid, and stannous chloride produce a state that readily ylelds the hydrated dioxide, judging from 1ts coprecipitation with the analogous rhenium compound $^{15}$. It is not clear whether this state is responsible for the yellow thiocyanate complex of Tc(IV) observed by Crouthamel $^{2}$. The dioxide can also be made by electrolytic reduction of pertechnetate solutions 30 , by hydrolysis of $\mathrm{TcCl}_{6}=$, and by reduction of $\mathrm{TcO}_{4}{ }^{-}$by 2 inc in dilute hydrochloric acid solutions 31 .

Th1s state of TC(IV) is oxidized to TC(VII) by nitric ac1d, hydrogen peroxide, and atmospher1c oxygen. It is carrled by ferric hydroxide, and one may take advantage of this fact to separate technetium rrom rhentum ${ }^{15}$.

Reduction of $\mathrm{TCO}_{4}{ }^{-}$to a cation1c form of $\mathrm{Tc}$ (IV) has been reported by de Carvalho ${ }^{32}$, using hydrazine at pH 8 to 9 or hydriodic ac1d as reductants. The assignment of a cationic character to this species was based on 1ts 1mmob1lity in. paper electrophores1s. However, this behavior is equally consistent with that of an insoluble substance, such as $\mathrm{TcO}_{2}$.

Strong hydrochlor $1 \mathrm{c}$ ac1d reduces $\mathrm{TcO}_{4}{ }^{-}$to $\mathrm{TcCl}_{6}=15,33$, though the reaction $1 \mathrm{~s}$ slow and proceeds through several Intermediate oxidation states. At room temperature, $1 \mathrm{hr}$. is required for complete reduction ${ }^{15}$. The reduction has also been carried out w1th 1odide 1 on 6,31 . The $\mathrm{TcCl}_{6}=$ ion under- 
goes slow hydrolysis even in $3 \underline{F} \mathrm{HCl}$, Judging from changes in 1ts absorption spectrum ${ }^{19}$. Reduction of $\mathrm{TcO}_{4}^{-}$by $\mathrm{SnCl}_{2}$ in 1-2M HCl gives a new TC(IV) species with a UV-absorption band at $3220 \mathrm{~A}^{34}$. In $0.75-0.5 \mathrm{M} \mathrm{HCl}$, a second oxygenated specles, with an absorption band at $3500 \mathrm{~A}$ was obtalned in addition. Hexachlorotechnetate (IV) Ion coprecipitates with thallium and $\alpha-\alpha$ ' dipyridyl hexachlororhenates (IV), but is not carried by cupferrates, phosphates and phenylarsonates of tetravalent cations ${ }^{15}$. In basic solution, it hydrolyzes promptly to the dioxide, which is carried by ferric hydrox$1 \mathrm{de}^{15}$. A separation from rhenlum may be based on this fact. Pertechnetate 18 reduced to $\mathrm{TCCl}_{6}=$ by conc. $\mathrm{HCl}$, the technetium is coprecipitated with $\mathrm{Fe}(\mathrm{OH})_{3}$, and oxidized to the +7 state by dissolving the precipltate in conc. $\mathrm{HNO}_{3}$. The iron is then removed by an ammonia precipitation ${ }^{15}$.

Thomason 35 has observed a plnk species of Tc(IV) during electrolytic reduction of a pertechnetate solution in the presence of phosphate 1on. Nothing 18 known about the analytical behavior of this species.

The $\mathrm{TCCl}_{6}=$ ion 18 oxidized to Tc(VII) by $\mathrm{HNO}_{3}, \mathrm{H}_{2} \mathrm{O}_{2}$, $\mathrm{Cl}_{2}, \mathrm{Ce}$ (IV) and $\mathrm{MnO}_{4}^{-15,28}$, but seems to be more resistant to air oxidation than the oxygenated spec1es of Tc(IV).

\section{c. Oxidation States +6 and +5}

These states are somewhat harder to prepare than the +4 state, and have not been too well characterized.

Gerlit ${ }^{15}$ obtained $T c(V I)$ by hydrazine reduction of cold, alkaline pertechnetate solutions. Since h1s experiments were carried out w1th $6 \mathrm{hr}$. Tc $99 \mathrm{~m}$, the compound could not be 1solated but had to be characterlzed by radiochemlcal techniques. It is nelther extracted by ketones or pyridine, nor precip1tated by ferric hydroxide, but is carried quantitatively by 
molybdenum 8-hydroxyquinolate, and silver and lead molybdate. In the presence of dioximes, it can be extracted into inert solvents such as chloroform. At an $\mathrm{OH}^{-}$concentration of 0.02 to $0.05 \mathrm{~N}$ the compound slowly disproportionates to $T c(V I I)$ and Tc(IV) in the ratio of $\sim 2: 1$. The above facts are consistent with its identification as $\mathrm{TcO}_{4}=$

Another oxidation state of technetium has been observed in the reduction of $\mathrm{TCO}_{4}{ }^{-}$to $\mathrm{TcCl}_{6}=$ by $6-8 \mathrm{M} \mathrm{HCl}$. At $100^{\circ} \mathrm{C}$, the reaction is complete in $\sim 12$ hours. During the first two hours, an intermediate oxidation state forms that extracts into hexone with a partition coefficlent of $>30$ (compared to $\sim 11$ for $\mathrm{TCO}_{4}^{-}$), absorbs light strongly at $2350 \AA$ (molar absorbancy, $\varepsilon \approx 3 \times 10^{4}$ ), and forms a red complex w1th thiocyanate ${ }^{33}$. Crouthamel ${ }^{2}$ was able to show that this complex $(\varepsilon=52,200$ at $5130 \AA)$ is due to $\mathrm{Tc}(\mathrm{V})$. It can be produced directly from Tc(VII), since thiocyanate 1tself w1ll reduce $T c(V I I)$ to $T c(V)$. Unfortunately, both Mo and Re Interfere by partial reduction to colored, extractable thiocyanate complexes, and by causing side reactions that prevent complete conversion of $T c(V I I)$ to $T c(V)$. Interestingly enough, stronger reducing agents such as $\mathrm{SnCl}_{2}$ also interfere, by carrying the reduction below the +5 state. This explains the observations of Perrier and Segre 20 that technetium does not extract into ether in the presence of thiocyanate and stannous chloride.

Crouthamel also obtained evidence for the formation of Tc(VI), (V), and (IV) in the potentiometric titration of $\mathrm{TcO}_{4}{ }^{-}$by $\mathrm{TI}$ (III) in $12 \mathrm{M} \mathrm{H}_{2} \mathrm{SO}_{4}$. In this medium, $\mathrm{Tc}(\mathrm{VI}) \mathrm{d} 1 \mathrm{~s}-$ proportionates within 3-4 minutes to $\mathrm{Tc}(\mathrm{V})$ and $\mathrm{Tc}(\mathrm{VII})$, whereas TC(V) disproportionates to Tc(VII) and TC(IV) within an hour. In $2 \mathrm{M} \mathrm{H}_{2} \mathrm{SO}_{4}$ or $\mathrm{HCl}$, saturated with $\left(\mathrm{NH}_{4}\right)_{2} \mathrm{SO}_{4}$ and 
$\mathrm{NH}_{4} \mathrm{Cl}$, respect1vely, a red color (absorption maximum $\sim 5000 \AA$ ) was observed at the stoichiometric endpoint of $\mathrm{Tc}(\mathrm{V})$. No such color was observed in 10 to $12 \underline{M}$ ac1d.

Busey ${ }^{34}$ has recently studied the reduction of $\mathrm{TcO}_{4}{ }^{-}$by HCl, confirming some of the observations of crouthamel ${ }^{2}$ and Alperovitch 33 . Reduction with $\mathrm{HCl}$ alone, or $\mathrm{H}_{3} \mathrm{PO}_{2}$ in 8 M HCl, gives what appears to be a singly oxygenated species of $\mathrm{Tc}(\mathrm{V})$, such as $\mathrm{TCOCl}_{4}{ }^{-}$. It is stable in $3 \mathrm{M} \mathrm{HCl}$, but disproportionates in $1 M \mathrm{MCl}$. A different species of $\mathrm{TC}(\mathrm{V})$, possibly $\mathrm{TcCl}_{6}{ }^{-}$, is formed when a solution of $\mathrm{TcCl}_{6}=$ in $12 \underline{M}$ HCl 18 irradiated in sunlight.

d. Oxidation state +3 and unidentifled lower states

Thomason has prepared a green solution contalning Tc(III) by controlled sathode potential electrolysis of $\mathrm{TcO}_{4}^{-}$in a phosphate buffer at pH $7^{35}$. It is easily oxidized by a1r to Tc(IV). Gerl1t ${ }^{15}$ reports that an oxidation state lower than (IV) is obtained in the reduction of $\mathrm{TcO}_{4}^{-}$by $\mathrm{Zn}$ in concentrated $\mathrm{HCl}$. This state does not coprecipitate w1th thallium hexachlororhenate (IV) from hydrochloric ac1d solutions, with rare earth or alkaline earth oxalates from weakly acld or neutral solutions, or with copper and zinc sulfides from weakly acid solutions. It is carried quantitatively by Iron and zirconium hydroxides, and the sulphide, hydroxide, and 8-hydroxyquinolate of manganese. It is readily oxidized by oxygen, hydrogen peroxide and nitric acid. Although Gerlit interprets this oxidation state as Tc(II), the above evidence definitely does not rule out 1ts assignment to Tc(III). For comparison, one should note that in dilute( 1 N) HCl, technetium is quantitatively deposited on amalgamated zinc powder ${ }^{23}$.

It is not known whether these species are cationic, nor have any other cationic states of Tc been identified with any 
certainty. Flagg and Bleldner ${ }^{22}$ report that solutions of electrodeposited $\mathrm{Tc}\left(\mathrm{TcO}_{2}\right.$ ?) in dilute ac1ds, and pertechnetate solutions treated with $\mathrm{HCl}$ or $\mathrm{SnCl}_{2}$ were adsorbed on basic alumina columns, suggesting reduction to a cation. Boyd et al 36 conducted electromigration experiments on $\mathrm{TcO}_{4}{ }^{-} \mathrm{solu}-$ tions in $4 \mathrm{M} \mathrm{H}_{2} \mathrm{SO}_{4}$. Their results indicated the presence of both cationic and anionic species, but since pure $\mathrm{ReO}_{4}{ }^{-}$solutions gave the same results, the evidence is not conclusive. Some adsorption on cation exchange resin was observed for $\mathrm{TCO}_{4}{ }^{-}$solutions in $\mathrm{I-2} \mathrm{N} \mathrm{H}_{2} \mathrm{SO}_{4}$ and $0.25-0.75 \mathrm{~N} \mathrm{HNO}_{3} 27,35$, but the exchange was irreversible and may have been due to precipltation of $\mathrm{TcO}_{2}$ on the resin.

A technetium-phthalocyanin complex of unspecifled valence has been used to separate Tc and Re, using the copperphthalocyanin complex as a carrier 37 . Rhenlưm does not form such a complex.

\section{Volatilization Methods}

Owing to the volatility of $\mathrm{Tc}_{2} \mathrm{O}_{7}$, technetium in the +7 oxidation state may be co-distilled with acids. An 1llustrat1ve graph has been given by Boyd et a1 23 .

Perchloric acid. This acid gives good ylelds and even a partial separation from rhenium 16,38 , but since 1t oxidizes ruthenlum to the volatile $\mathrm{RuO}_{4}$, a TC-Ru separation in the distillate is required. Glendenin ${ }^{16}$ reduced $\mathrm{RuO}_{4}$ to insoluble $\mathrm{RuO}_{2}$ by bolling the distillate (collected in excess $6 \underline{\mathrm{N}} \mathrm{NaOH}$ ) with alcohol for $1-2$ minutes. The TC and about $1 \%$ of the Ru remained in the solution. Unfortunately, further separations by solvent extraction of $\mathrm{TcO}_{4}^{-}$are not feasible in this medium, since perchlorate interferes.

Molybdenum is also carried to a significant extent, unless complexed by phosphoric ac1d 39,40 . 
Sulfur1c ac1d. In this medium, a clean separation from Ru may be obtained ${ }^{16}$, with separation factors of $10^{5}$ or better, but the yields of Tc are occasionally very poor due to 1 ts reduction by trace impurities in the acid 23,28 . Much more reproducible results are obtained in the presence of oxidizing agents [e.g., Ce(IV), $\mathrm{CrO}_{3}$, etc.], but since RuO 4 distills under these conditions, it has to be removed in a separate step such as precipitation of $\mathrm{RuO}_{2}$ with alcohol or formaldehyde 16,20 . Some effort should be made to find an oxidizing agent that is non-volatile, stable in bo1ling sulfuric ac1d, strong enough to keep TC in the +7 state, yet not so strong as to oxidize lower states of $\mathrm{Ru}$ to $\mathrm{RuO}_{4}$. If Ru contamination is not a problem, Ce(IV) may be used to advantage. It is stable, non-volatile, and changes color on reduction.

In the distillation of sulfuric acid-water mixtures, a substantial fraction of the Tc distills with the low-bolling aqueous fraction, possibly as $\mathrm{HTCO}_{4}$. Once the water has been removed, the distillation appears to follow a first-order rate law (Fig. 2), the rate constant depending on the st1ll design and reflux ratio. To avold contamination by spray, a Kjeldahl head should be used. For optimum reproducibllity, 1t is advisable to heat the flask electrically, by means of a heating mantle with quartz fabric insulation.

Sulfuric ac1d-hydrochloric ac1d. When 6 N HCl is distilled into $80 \% \mathrm{H}_{2} \mathrm{SO}_{4}$ at $180-200^{\circ} \mathrm{C}$, Re volatilizes while most of the TC is reduced to the non-volatile +4 state and stays behind 20 . Separation factors of up to 50 have been obtained by this procedure 27 .

Other systems. Because of the great differences in vapor pressures of the acids and heptoxides at low temperatures, Tc 


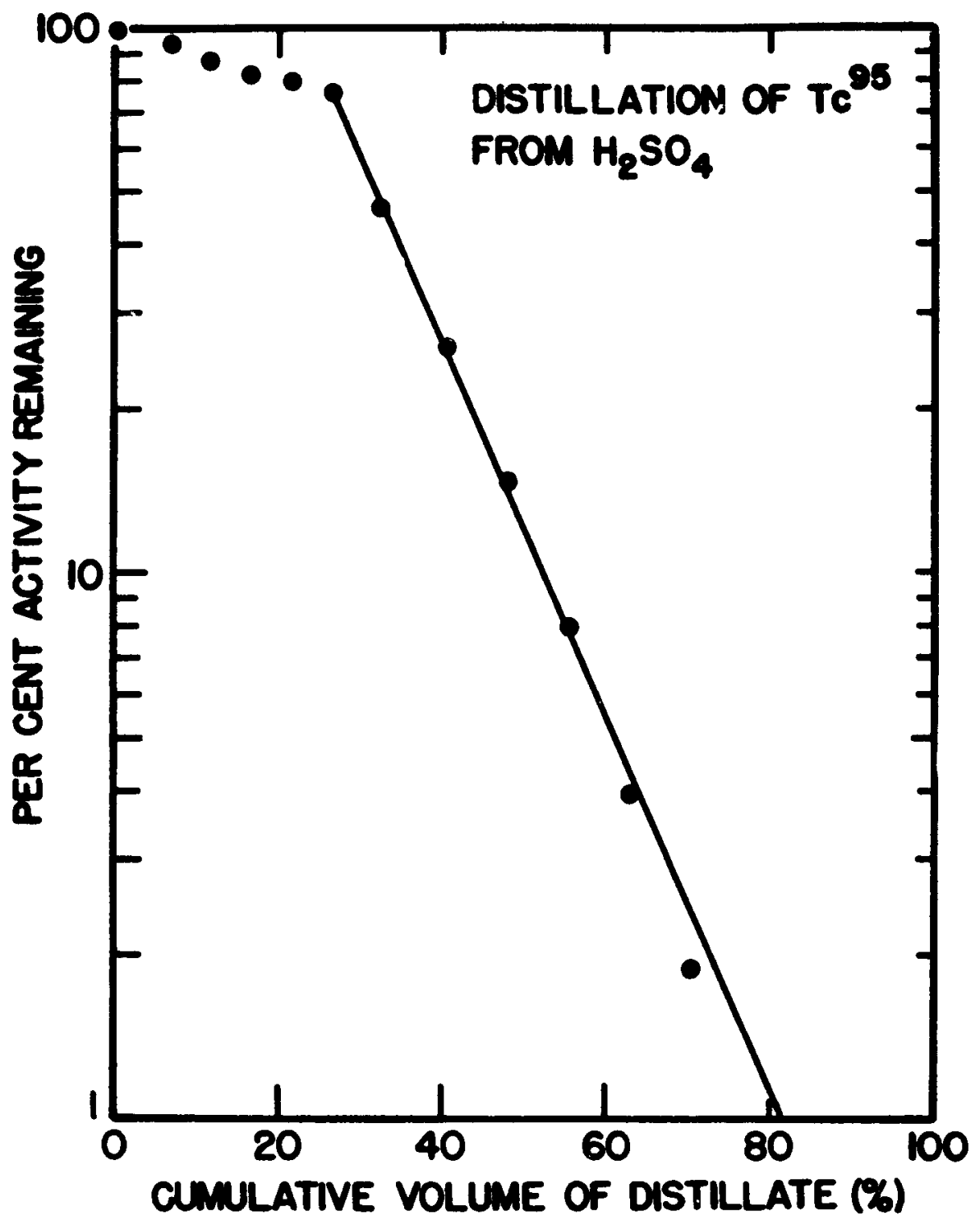

F1g. 2.

Distillation of $\mathrm{TcO}_{4}{ }^{-}$from mixture of $\mathrm{H}_{2} \mathrm{SO}_{4}(10 \mathrm{ml})$ and $\mathrm{H}_{2} \mathrm{O}(3.5 \mathrm{ml})$ in the presence of $0.5 \mathrm{mililmoles} \mathrm{CrO}_{3}$. Distillation rate: $0.5 \mathrm{ml} / \mathrm{min}$. 
may be separated from Re by repeated alternating evaporation with $\mathrm{HNO}_{3}$ and $\mathrm{HCl}{ }^{4 I}$. The technetium in the distillate may be coprecipitated with tetraphenylarsonium perchlorate.

Technetium heptoxide may be separated from molybdenum trioxide by fractional sublimation at $\geqslant 300^{\circ} \mathrm{c}^{6,20}$. RuthenIum and technetium can be separated from bas1c solution by dist1lilng $\mathrm{RuO}_{4}$ in a chlorine stream ${ }^{42}$. Rhenium and technetium volatilize if the sulfides are heated to $100^{\circ} \mathrm{C}$ in a chlorine stream ${ }^{20}$, but this reaction has not been used for chemical separations.

5. Extraction of technetium into organic solvents Pyridine. Go1sh1 and Libby 43 found that pyridine extracts $\mathrm{TcO}_{4}$ - from $4 \mathrm{~N}$ NaOH solution with a partition coefricient

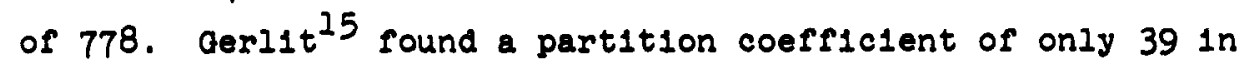
$5 \mathrm{~N} N a O H$, and cla1ms that Mo(VI) and Ru(IV) are extracted to a substantial degree. Perrhenate and permanganate are also extracted under these conditions.

Tetraphenylarsonium chloride. Pertechnetate also extracts into chloroform in the presence of tetraphenylarsonium $10 n^{3}$. The equilibrium constant for the reaction:

$$
\left[\left(\mathrm{C}_{6} \mathrm{H}_{5}\right)_{4}^{\mathrm{As}^{+}}\right]_{\text {aq }}+\mathrm{TcO}_{4}^{-} \leq\left[\left(\mathrm{C}_{6} \mathrm{H}_{5}\right)_{4} \mathrm{AsTcO}_{4}\right]_{\text {org }}
$$

is $\sim 3 \times 10^{6}$. The corresponding constant for chloride is $200^{3}$. At chloride concentrations of $1 \underline{M}$ or less, distribution coefficlents as large as 100 can easily be realized at reagent concentrations of $7 \times 10^{-3} \mathrm{M}$. In neutral or basic sulfate solutions the distribution coefficients are even more favorable. Perrhenate and perchlorate follow technetium in this extraction, but molybdenum does not interfere in basic solution, and the decontamination from other fission products 
should be at least as good as in the precipitation reaction ${ }^{17}$, if care is taken to remove lodine before extraction. Trivalent gold as chloro- or bromoaurate is also extracted and must be removed by reduction with $\mathrm{H}_{2} \mathrm{O}_{2}$, or by distillation.

It is advisable to have small amounts of an oxidizing agent, such as hydrogen peroxide, present during the extraction, so that $\mathrm{TcO}_{4}^{-}$will not be reduced by impurities in the reagent. Any wash solutions used should contain a sufficient concentration of tetraphenylarsonium ion (about $5 \times 10^{-5} \underline{\mathrm{M}}$ ) to prevent premature back-extraction of $\mathrm{TcO}_{4}^{-}$into the aqueous layer.

The technet1um may be recovered from the organic phase by back-extraction Into $0.2 \mathrm{~N} \mathrm{HClO}_{4}$ or $12 \mathrm{~N} \mathrm{H}_{2} \mathrm{SO}_{4}$. In the latter case, three back-extractions are required.

Other organic solvents. Extraction of $\mathrm{TcO}_{4}^{-}$into hexone, butex, and other solvents has also been invest1gated $27,32,44$ None of these extractions will separate Tc from Re, but they may serve to separate it from molybdenum and many other elements. Of particular interest are the recent extensive studies of Gerl1t G $^{15}$ and Boyd \& Larson 45,46 . Gerlit investigated the extraction of $\mathrm{TC}(\mathrm{VII}), \operatorname{Re}(\mathrm{VII}), \mathrm{Mo}(\mathrm{VI})$ and $\mathrm{Ru}(\mathrm{IV})$ into 21 organic solvents, from ac1d, alkaline, and neutral solutions. In acid solution, alcohols, ketones, and tributyl phosphate are the best extractants for $\mathrm{ReO}_{4}{ }^{-}$and $\mathrm{TcO}_{4}{ }^{-}$; in bas1c solution, ketones and cyclic amines. Many possible separations of TC from $R u$ and Mo may be inferred from h1s data. For example, in $5 \underline{N} \mathrm{NaOH}$, hexone extracts Tc(VII), Re(VII), Mo(VI) and Ru(IV) with partition coefficients of $17,8.2,<0.001$ and $<0.001$. Boyd \& Larson conducted an exceedingly thorough study of the extraction behavior of $\mathrm{TCO}_{4}{ }^{-}$in 34 solvents, and found that tertiary amines as well as quaternary ammonium saits gave the 
largest partition coefficients. Strongly basic solvents (e.g. amines) extract $\mathrm{TCO}_{4}^{-}$as an "-onlum" salt, whereas solvents of lower basicity extract elther free pertechnetic ac1d or an Inorganic pertechnetate $15,45,46$. In the former case, the partition coefficient decreases with increasing salt concentration, whereas the reverse is true in the latter case ${ }^{15}$.

Back-extraction of the technetium into the aqueous phase may be accomplished in several ways. In some cases, a $\mathrm{pH}$ change will suffice; in others, displacement by another anion such as perchlorate, nitrate, or blsulfate is most effective. A third possibility was pointed out by Gerlit: the partition coefficient in a given oxygen-containing solvent may be decreased sufficiently by addition of a non-polar solvent to permit quantitative back-extraction into the aqueous phase. Extraction of lower oxidation states. It seems that many new separations could be developed, based on selective reduction of TC(VII) to lower oxidation states. The red thlocyanate complex of $\mathrm{Tc}(\mathrm{V})$ extracts well into alcohols, ethers, and ketones $2,15,33$, and into a solution of trioctylphosphine oxide or trioctylamine hydrochloride in cyclohexane or 1,2-dichloroethane 19 . The extractabll1ty of TC(VI) has already been mentioned. The $\mathrm{TCCl}_{6}=1$ on w111 extract into chloroform in the presence of fairly high concentrations of tetraphenylarsonium 1on 33 , but nothing else seems to be known regarding the solvent extraction behavior of the lower oxidation states of technetium.

The principal disadvantage of all extraction methods is the Inevitable introduction of organic matter which may reduce $\mathrm{TcO}_{4}{ }^{-}$and cause difficulties in subsequent steps.

6. Chromatographic Behavior of Technetium Pertechnetate ion is very strongly adsorbed by strong- 
base anion exchangers $27,36,47,48$, and can be eluted only by Ions with very high affinity for the resin, such as perchlorate and salicylate. Perrhenate is almost as strongly held (the ratio of distribution coefficlents is $\sim 1.6$ to $2,1 . e$. comparable to adjacent rare earths). These two elements may therefore be separated by Ion-exchange chromatography, but good separations require some care, and tend to be slow

$(\geqslant 3$ hours). Even in less dellcate separations, such as TC-Mo, not much time can be gained, since the elution of the strongly adsorbed $T C$ is bound to be time-consuming. However, cation-exchange resins adsorb technetium only to a negligible extent, so that technetium can be rapidly separated from cationic elements.

Th1ocyanate. Atteberry and Boyd ${ }^{49}$ separated $\mathrm{TcO}_{4}{ }^{-}$and $\mathrm{ReO}_{4}{ }^{-}$on Dowex-2 resin (sulfate form), using an ammonium sulfate-thiocyanate solution at $\mathrm{pH} 8.3-8.5$. The two peaks were partially resolved, but the cross-contamination was rather high. Hall and Johns 50 separated technetium from molybdenum, using Amberlite IRA-400 resin and 0.5 M ammonium thiocyanate.

Perchlorate. Much better results are obtalned if perchlorate ion is used as the elutriant $4,33,51,52$. Berause of some peculiarities of commercial resins, the highest practically attainable separation factors of $\mathrm{TcO}_{4}^{-}$and $\mathrm{ReO}_{4}^{-}$are $10^{4}-10^{5}$. On Dowex-1 (8\% crosslinkage), the peak elution volumes of $\mathrm{ReO}_{4}{ }^{-}$and $\mathrm{TCO}_{4}^{-}$in $0.2 \mathrm{M} \mathrm{HClO}_{4}$ are $23.6 \pm 0.4$ and $43.7 \pm 0.7$ free column volumes, respectively ${ }^{4}$ (Fig. 3). They are virtually the same in ammoniacal ammonium perchlorate solutions, and are very nearly inversely proportional to the first power of the perchlorate concentration.

In past work, where speed was not essentlal, flow rates 


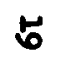

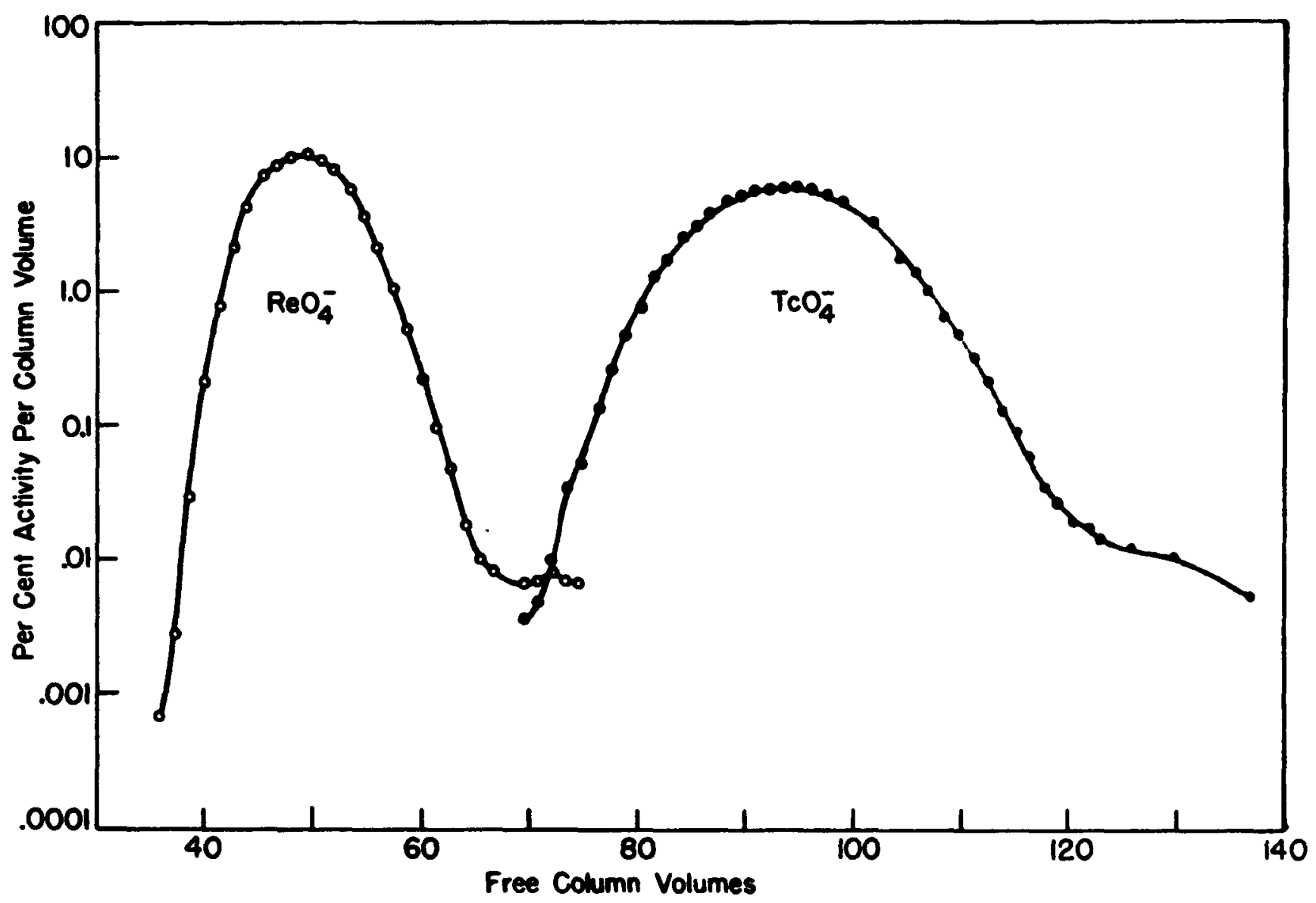

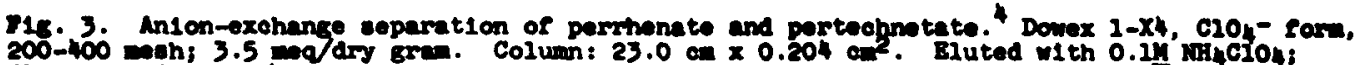

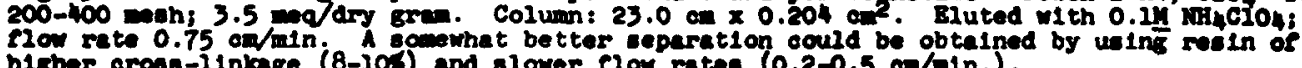


of $0.2-0.4 \mathrm{~cm} / \mathrm{min}$ have generally been used, at perchlorate concentrations of 0.1 to $0.25 \mathrm{M}$. For columns of $10-20 \mathrm{~cm}$ length, times on the order of a day are required for a separation. It should be possible to reduce this time substantially by choosing the optimum elution conditions from Glueckauf's graphs 53 . Molybdenum is also adsorbed by anton exchange resins, and may be eluted by hydroxide 52,54 , oxalate ${ }^{50}$, or hydrochloric ac1d 55 , though in the last two cases, there is some danger of reducing Tc (VII). Separation factors of $>10^{3}$ should be readily attainable.

Hydrochloric ac1d. In this medium, the voluine distribution coefficlents for $\mathrm{TcO}_{4}{ }^{-}$on Dowex-1 range from $10^{2}$ to $10^{3}$, according to Kraus et al ${ }^{47}$. Somewhat hlgher values have been given by Huffman et al ${ }^{48}$. At higher concentration, it is reduced to $\mathrm{TCCl}_{6}=$, which is held even more strongly 33 .

Nitric ac1d. Technetium can be eluted from Dowex-1 with $4 \mathrm{~N} \mathrm{HNO}_{3}$ at reasonable rates ${ }^{48}$. At this concentration, the volume distribution coefficient is about 20 . Huffman et al 48 have developed a separation of Mo and Tc, Involving elution of Mo(VI) by I $\mathrm{M} \mathrm{HCl}$, and $\mathrm{Tc}$ (VII) by $4 \mathrm{MNO}_{3}$. The only drawback of this separation is the need to recover TC from an $\mathrm{HNO}_{3}$ solution. If the ac1d is evaporated with.great care, losses may be kept quite low, but this step is far from foolproof.

Paper chromatography. Technetium can also be separated from molybdenum by paper chromatography 56 and electrophores1s 32 . The separation from rhenium is incomplete under most conditions except when Tc is selectively reduced by $\mathrm{HCl} 57$, $\mathrm{HI}$, or hydrazine 32 .

\section{Electrochemical Behavior}

Technetium can be electrodeposited as the dioxide from 
2 M NaOH ${ }^{30}$. A partial separation from Mo and Re may be obtained at a controlled cathode potentlal of $-1.1 \mathrm{~V}$ vs. the saturated calomel electrode, but the deposition only takes place at technetium concentrations of $10^{-4}$ M or greater. Flagg and Bleldner ${ }^{22}$ electrolyzed carrier-free Tc $95+96$ on a platinum cathode in dilute $\mathrm{H}_{2} \mathrm{SO}_{4}(\mathrm{pH}=2.36)$ and obtained a $99.5 \%$ yield after 65 minutes at $-0.8 \mathrm{~V}$ vs. the saturated calomel electrode.

Boyd et al ${ }^{23}$ have electroplated technetium under a variety of conditions. Optimum results were obtained at $\mathrm{pH} 5.5$ in the presence of about $10^{-3} \underline{\mathrm{M}}$ fluoride 1on. Yields were higher when copper cathodes were used instead of platinum. At a current density of $100 \mathrm{ma} / \mathrm{cm}^{2}, 89.5 \pm 1.5 \%$ was deposited in 2 hours. However, y1elds of 98-99\% were obtained at similar current densities even for Pt cathodes, at pH 2 to 5, and fluoride concentrations of $5 \times 10^{-3} \underline{M}$, when plating times of up to $20 \mathrm{hrs}$. were used 28 .

In $2 \mathrm{~N} \mathrm{H}_{2} \mathrm{SO}_{4}$ containing traces of fluoride, the electrodeposit consists of metallic technetium 9 , which is insoluble In ammoniacal hydrogen peroxide. The dioxide plated at lower ac1d concentrations will, however, dissolve in ammonia and hydrogen peroxide, sodium hypochlorite, and nitric ac1d.

\section{DISSOLUTION OF SAMPIES CONTAININO COMPOUNDS}

\section{OP TECHNETIUM}

When dissolving technetium-containing samples, two precautions should always be observed. P1rst, it is essential that acld solutions be heated only under reflux conditions, to prevent volatilization losses. Second, the dissolution should be done under strongly oxidizing conditions, to ensure conversion of all lower states to Tc(VII). Complications due 
to slow exchange with carrier, etc., are less likely to arlse for this state than for any other.

Molybdenum targets can be dissolved in nitric acid or aqua regia, but in both cases the excess ac1d interferes with many subsequent operations. These complications are avolded in the procedure of Boyd et al 23 , who dissolve molybdenum metal in concentrated sulfuric acid, and oxidize the solution with $\mathrm{H}_{2} \mathrm{O}_{2}$ after neutralization.

Other materials can often be brought into solution by fusion with $\mathrm{Na}_{2} \mathrm{O}_{2}-\mathrm{NaOH}$ fluxes.

V. COUNTING TECHNIQUES FOR USE WITH ISOTOPES

OF TECHNETIUM

1. Counting

The $\beta$-emitt1ng 1sotopes, $\mathrm{Tc}^{92}, \mathrm{Tc}^{94}$, and $\mathrm{Tc}^{998}-\mathrm{Tc}^{105}$, can be counted in $G-M$ or $\beta$-proportional counters in conventional manner. Most of the remaining light 1sotopes decay largely by electron capture or 1someric transition, with the emission of $\boldsymbol{\gamma}$-rays or $\boldsymbol{x}$-rays, and can therefore be measured by $\gamma$-scintillation or $x$-ray proportional counters. The former method is particularly useful for $\mathrm{Tc}^{95}$ (201 kev $\boldsymbol{\gamma}$ ), Tc $99 \mathrm{~m}$ (141 kev $\gamma$ ) and $\mathrm{Tc}^{96}$ (several $\boldsymbol{\gamma}^{\prime} \mathrm{s}$ in the range $0.771-0.842 \mathrm{Mev}$ ). The 1sotope Tc 978 emits only Mo $x$-rays in 1ts decay, and must therefore be counted on an $x$-ray proportional counter. This is also true of $\mathrm{Tc}^{97 \mathrm{~m}}$, since 1 ts $97 \mathrm{kev} \gamma$-ray is highly Internally converted, and the conversion electrons are too soft to be counted conveniently.

The $1.5 \times 10^{6} \mathrm{y} \mathrm{Tc}^{98}$ presents somewhat of a problem, since It cannot be produced free of $60 \mathrm{~d} \mathrm{Tc} 95,90 \mathrm{~d} \mathrm{Tc}^{97 \mathrm{~m}}, 2.6 \times 10^{6} \mathrm{y}$ $\mathrm{Tc}^{97 \mathrm{~g}}$, and $2.1 \times 10^{5} \mathrm{y} \mathrm{Tc}^{99 \mathrm{~g}}$. Fortunately, 1 t emits two $\boldsymbol{\gamma}$-rays of 0.769 and $0.669 \mathrm{Mev}$ in coincidence with a $0.3 \mathrm{Mev} \beta^{-}$, and 
can therefore be counted selectively in the presence of much larger amounts of the other 1sotopes.

\section{Chemical Yield Determination}

Technetium does not have a stable 1sotope that can be used as a carrier, and although there are many excellent non1sotop1c carriers available (e.g., insoluble perrhenates and perchlorates, and the sulfides of copper, platinum, and rhenlum) the inevitable fractionation between these carriers and technetium makes it 1mpossible to obtain accurate chemical ylelds.

Fortunately, the radiations and half-lives of technetium 1sotopes are sufficiently diverse to permit their use in yleld determinations. For example, the $60 \mathrm{~d} \mathrm{Tc}^{95}$ has been used as a yleld monitor for $\mathrm{Tc}^{99 \mathrm{~m}}$ since 1 ts principal radiation, a 201 kev $\gamma$ ray interfered but slightly with the counting of the $140 \mathrm{kev} \gamma$ ray of the latter ${ }^{58}$. Moreover, the degree of interference could be easily determined and corrected for. Other 1sotopes that may be useful for yleld determinations are $6 \mathrm{~h} \mathrm{Tc} 99 \mathrm{~m}$, which emlts only the previously-mentioned 140 kev $\gamma$ ray, and sort conversion electrons; $2.12 \times 10^{5}$ year $\mathrm{Tc}^{99 \mathrm{~B}}$, a pure $\beta^{-}$-em1tter w1th $\mathrm{E}_{\max }=0.29 \mathrm{Mev}$, and $91 \mathrm{~d} \mathrm{Tc}^{97 \mathrm{~m}}$, which emits only TC $x$-rays and a highly internally converted $\gamma$ ray of $96 \mathrm{kev}$ energy.

In each case, the chemlcal yleld of the "yleld monitor" may be determined by selective counting, before or after the decay of the principal activity. In the case of $\mathrm{Tc}^{99}$, chem1cal analysis by colorimetric ${ }^{2}$ or other methods is possible, but even for this long-lived 1sotope, the specific activity Is so high $\left(3.78 \times 10^{4} \mathrm{~d} \mathrm{~min}^{-1} \mu \mathrm{g}^{-1}\right)$, that the amounts likely 
to be used for yield monitoring can be measured more accurately by $\beta$-counting than by chemical methods.

VI. Collection of Detalled Radlochemical Procedures for Technetlum Procedure 1

Source - G. E. Boyd, Q. V. Larson and

E. E. Motta, JACS $\underline{82}, 809$ (1960)

Isolation of $\mathrm{Tc}^{95 \mathrm{~m}}+\mathrm{Tc}^{96}$ from Molybdenum

\section{Introduction}

Th1s is probably the best, though not the fastest, procedure for separating TC from a molybdenum target. It involves separation of molybdenum by anion exchange chromatography. If a separation from rhenlum is required, elther Proced. 4 or 14 may be used subsequently.

\section{Procedure}

The molybdenum target was dissolved in concentrated $\mathrm{H}_{2} \mathrm{SO}_{4}$ under reflux, the ac1d was neutralized with $\mathrm{NaOH}$ and the solution was treated with $\mathrm{H}_{2} \mathrm{O}_{2}$ to oxldize technetium to Tc(VII). Th1s alkaline solution was passed through a small column of anton exchanger (Dowex-1,21 x $50 \mathrm{~mm}$.) which absorbed the pertechnetate Ion completely. Resldual absorbed molybdate. was removed by elution with I $\mathrm{M} \mathrm{K}_{2} \mathrm{C}_{2} \mathrm{O}_{4}$ solution, and, after a water rinse, the technetium was eluted with $1.0 \mathrm{~N} \mathrm{HClO}_{4}$. A concentration of the technetium activity was effected by precipitating Cus from the ac1d. Subsequently, the sulfide was dissolved in alkaline hydrogen peroxide, and the copper was removed by passing the resulting solution through a micro-column of cation exchanger (Dowex-50). The technetium contained in the effluent was electrodeposited onto a platinum cathode, dissolved in ammoniacal hydrogen peroxide, evaporated to dryness in a platinum 
dish and the resulting ultra-micro quantities of $\mathrm{NH}_{4} \mathrm{TcO}_{4}$ were made to $5 \mathrm{ml}$. volume in a volumetric rlask.

\author{
Procedure 2 \\ Source - S. Tribalat, J. Beydon, Anal. \\ Chim. Acta 8, 22 (1953) \\ Separation of Technetium from Molybdenum
}

\title{
1. Introduction
}

Th1s procedure 18 based on the extraction of pertechnetate into chloroform in the presence of tetraphenylarsonium 1on. It $1 \mathrm{~s}$ fast and gives good separations. In order to keep the reagent concentration in the rinal solution as low as possible, the extraction 18 carried out at $R=5 \times 10^{-5} \mathrm{M}$.

\section{Procedure}

Ten grams $\mathrm{MOO}_{3}$ are dissolved in $20 \mathrm{ml} \mathrm{H}_{2} \mathrm{O}$, containing $0.1 \mathrm{~g} \mathrm{Na} \mathrm{S}_{2} \mathrm{O}_{8}$ and the minimum amount of $10 \mathrm{~N} \mathrm{NaOH}$. (Note 1 ). The $\mathrm{pH} 18$ adjusted to 10-1I by addition of $\mathrm{NaHCO}_{3}$, if necessary, the solution $1 \mathrm{~s}$ made $5 \times 10^{-5} \underline{\underline{M}}$ in tetraphenylarsonium ion, and $1 \mathrm{~s}$ shaken w1th $50 \mathrm{ml}$ freshly purified $\mathrm{CHCl}_{3}$ for $5 \mathrm{~min}$. The distribution coefficient is about 15 .

The organic layer 18 filtered through filter paper molstened with chloroform, dried with $\mathrm{Na}_{2} \mathrm{SO}_{4}$, refiltered, and washed with $30 \mathrm{ml}$ very dilute $\mathrm{NaOH}(\mathrm{pH} \mathrm{10-11).} \mathrm{The} \mathrm{solution}$ is refiltered, and the technetium is recovered from the organtc phase by prolonged shaking with water. In general, no more than $15 \%$ of the TC should remain in the chloroform and the first wash. 
Source - J. Flegenhelmer and W. Seelmann-Eggebert,

Proc. Intern. Conf. Peaceful Uses of Atomic

Energy, Geneva, 1955, 7, 152 (1956)

$$
\text { Separation of } \mathrm{Tc}^{102} \text { and } \mathrm{MO}^{102}
$$

1. Introduction

Th1s is the fastest known procedure for the separation of TC and Mo. It is based on precipitation with tetraphenylarsonium ion. The yield is not quantitative, and the separation is not complete, but the sample can be counted within 5-6 seconds after the separation.

\section{Procedure}

The lead molybdate sample is dissolved in a mixture of tartarlc and hydrochloric ac1ds in the presence of $\mathrm{ReO}_{4}$ carrier. (Note 1). The solution is transfered to a Buichner funnel with detachable top, fitted with a membrane filter and mounted on a filter flask. The entire assembly is placed directly below a GM counter. Tetraphenylarsonlum chloride solution is added, and the suction is turned on. As soon as the solution has drained, the sample may be counted.

Note 1. The tartaric ac1d complexes the molybdenum, thereby preventing its precipitation. It would seem that an even cleaner separation might be obtalned from an ammoniacal ammonium tartrate solution. 


\section{Procedure 4}

\section{Source - R. N. Sen Sarma, Edward Anders, and J. M. Mllier, J. Phys. Chem. 63, 559 (1959)}

Separation of Technetium and Rhenium by Anton
Exchange

\section{Introduction}

Technetium and rhenium are separated by elution with perchlorate ion. Separation factors of up to $10^{5}$ are possible, but the method is slow ( 2 hrs. - 2 days). Any strong-base anion exchanger may be used.

\section{Procedure}

The solution containing $\mathrm{TCO}_{4}^{-}$and $\mathrm{ReO}_{4}^{-}$is concentrated to as small a volume as possible, and $1 \mathrm{~s}$ adsorbed on an anion exchange column in the perchlorate form. The colamn should be so large that 1 t 18 saturated to no more than $5 \%$ of 1 ts capac1ty, and the length/diameter ratio should be at least 30 . The resin particle size should be chosen so as to give flow rates of $0.2-0.5 \mathrm{~cm} / \mathrm{mln}$. At lower flow rates, "talling" Increases, and at higher flow rates, the peaks broaden excessively.

After the sample solution, followed by two rinses of 3 column volumes of water, has flowed through the column, the top section of the column 18 rinsed very. thoroughly, to prevent contamination of the elutriant with any rhenium that might have adhered to the walls. The elution 18 then performed with $0.1 \mathrm{M} \mathrm{HClO}_{4}$ or $\mathrm{NH}_{4} \mathrm{ClO}_{4}$. For Dowex-1X8 resin, the peak elution volumes of $\mathrm{ReO}_{4}{ }^{-}$and $\mathrm{TcO}_{4}{ }^{-}$are about 43 and 82 , respectively, so that a cut should be taken at about 60 free column volumes.

The technetium can be recovered from the perchlorate solution by electrolysis, by a sulfide precipitation, or by reduction to the 4 state and coprecipitation with $\mathrm{Fe}(\mathrm{OH})_{3}$. 


$$
\begin{aligned}
& \text { Procedure } 5 \\
& \text { Source - } \mathbf{E} \text {. Anders } \\
& \text { Separation of Tc } 99 \mathrm{~m} \text { from M1xed P1le } \\
& \text { Activities } \\
& \text { 1. Introduction }
\end{aligned}
$$

Th1s procedure combines solvent extraction by tetraphenylarsonium ion (Procedure 2) with a distillation step. It Is falrly fast ( $3 \mathrm{hrs}$.$) , and gives decontamination factors$ greater than $10^{4}$ for all pile-produced activities, except rhenlum. Ylelds are 50-80\%. It can be modifled to give a separation from rhenlum by adding an anion exchange step (Procedure 4), or a $\mathrm{TcO}_{2}$ coprecipltation with $\mathrm{Fe}(\mathrm{OH})_{3}$ (Procedure 14).

The samples used in this procedure were water-soluble concentrates that had been 1solated from minerals suspected to contain a long-11ved $\mathrm{Tc}^{98}$ 1somer (cr. Procedure 7). A molybdenum fraction was always separated to determine the contribution, if any, of $\mathrm{Tc}^{99 \mathrm{~m}}$ grown from Mo 99 to the observed Tc $99 \mathrm{~m}$ activity.

\section{Procedure}

(1) The sample is dissolved in $3 \mathrm{ml} 2 \mathrm{~N} \mathrm{NH}_{3}$ containing the following holdback carriers: $2 \mathrm{mg}$ Mo(VI), $1 \mathrm{mg}$ W.(VI), $0.5 \mathrm{mg}$ of $\mathrm{Sb}(\mathrm{V}), 1 \mathrm{\mu g}$ each of $\mathrm{Au}$ (III), As(V), $\mathrm{Zn}$ (II), $\mathrm{Cu}$ (II), $\mathrm{Ge}(\mathrm{IV})$. (Note I). Enough $30 \% \mathrm{H}_{2} \mathrm{O}_{2}$ is added to. convert all Mo to the red peroxymolybdate. The solution is heated on a water bath for 10 minutes, to ensure exchange with the carriers.

(2) The solution $1 \mathrm{~s}$ cooled and transferred to a $30 \mathrm{ml}$ Ultramax separatory funnel with teflon valve. Enough tetraphenylarsonium sulfate solution (Note 2) is added to give a final molarity of $\varnothing_{4} \mathrm{As}^{+}$of $\sim 10^{-3}$ (about 10 drops of 


\section{Procedure 5 (Continued)}

a $5 \times 10^{-2}$ N solution 18 required for a sample volume of 5-10 ml), $7 \mathrm{ml}$ of $\mathrm{CHCl}_{3}$ is added, and the technetium is extracted 1nto the chloroform.

(3) The chloroform layer 18 transferred to a second funnel, and 18 washed with $5 \mathrm{ml} 0.2 \mathrm{~N} \mathrm{NH}_{3}$ that $1810^{-4} \mathrm{~N}$ in $\left(\varnothing_{4} \mathrm{As}\right)_{2} \mathrm{SO}_{4}$. (Note 3 ).

(4) The chloroform layer from the preceding extraction is transferred to a third funnel, and is contacted with $5 \mathrm{mI} \mathrm{I} \mathrm{N} \mathrm{H}_{2} \mathrm{SO}_{4}$ that $1810^{-4} \mathrm{~N}$ in $\left(\emptyset_{4} \mathrm{AB}\right)_{2} \mathrm{SO}_{4}$. The chloroform layer 18 transferred to a fourth funnel.

(5) (Th1s step and the following one may be omitted if a slightly lower yleld can be tolerated.) The aqueous layer from step (2) 1 s again made $10^{-3} \mathrm{~N}$ in $\left(\phi_{4} \mathrm{As}\right)_{2} \mathrm{SO}_{4}$, and extracted with $7 \mathrm{ml} \mathrm{CHCl}_{3}$.

(6) The chloroform extract from step (5) 1s ouccessively contacted with the wash solutions from steps (3) and (4), and is then combined with the chloroform layer from Step (4).

(7) The combined chloroform extracts are shaken with three $7 \mathrm{ml}$ portions of $12 \mathrm{~N} \mathrm{H}_{2} \mathrm{SO}_{4}$ (Note 4). For a more complete back-extraction of the technetium, 1 drop of $0.2 \mathrm{~N} \mathrm{HClO}_{4}$ may be added to each $7 \mathrm{mI}$ portion of $\mathrm{H}_{2} \mathrm{SO}_{4}$.

(8) To remove any chloroform droplets, the combined aqueous layers are filtered through coarse, molst f1lter paper into a distilling rlask with air inlet tube. About I gram of cer1c sulfate $1 \mathrm{~s}$ added to the solution, along with one drop each of $0.2 \underline{\mathrm{MBr}}$ and $0.2 \mathrm{MBrO}_{3}$.

(9) The solution 18 heated to about $80^{\circ} \mathrm{C}$ for $10 \mathrm{~min}$. while bubbling a stream of nitrogen through 1t. Th1s should volatilize any bromine activity. 


\section{Procedure 5 (Continued)}

(10) Glass beads are added to the flask, a condenser with a Kjeldahl trap is attached, and the solution is distilled to near dryness at a rate of $1-1.5 \mathrm{ml} / \mathrm{min}$. (Note 5).

(11) The distillate is cooled in 1ce, $3 \mathrm{mg}$ of $\mathrm{Cu}^{2+}$ carrier is added, and the acidity is adjusted to 1 N by slow add1tion of conc. $\mathrm{NH}_{3}$.

(12) Thioacetamide in $5 \%$ solution $1 \mathrm{~s}$ added to give a concentration of $0.5 \%$, and the solution is heated to just below bolling for $40 \mathrm{~min}$. (Note 6 ). A wetting agent (e.g. Schlelcher \& Schuell Ant1-Creep) is added, and the solution is flitered through a coarse membrane f1lter. (Note 7). Note (1). Antimony and tungsten holdbacks are added in larger amounts since these elements tend to contaminate the molybdenum fraction.

Note (2). Tetraphenylarsonfum sulfate can be prepared from the chloride by passing a $0.05 \mathrm{~N}$ solution of the latter through a Dowex-I column in the sulfate form. Th1s conversion is desirable to prevent interference by chloride in the subsequent distillation.

Note (3). Some tetraphenylarsonium 1on must be present in the wash solutions, to prevent back-extraction of the technetium.

Note (4). The principal remaining impurities at this point are Au (extracted as chloro- or bromoaurate) and Br. Both will carry on a sulfide precipitate even in the presence of holdbacks, and must therefore be removed by distiliation. However, if they are known to be absent, the back-extraction can be done much more efflciently into $0.2 \mathrm{~N} \mathrm{HClO}_{4}$, in which case the technetium is isolated by 


\section{Procedure 5 (Continued)}

a sulfide precipitation. The perchloric acid solution cannot be distilled safely, owing to 1 ts content of organ1c matter.

Note (5). To prevent bumping, nitrogen should be bubbled through the solution. An electric heating mantle with quartz-fabric insulation may be used to advantage. Note (6). In $1 \mathrm{~N} \mathrm{H}^{+}$, technetium can normally be quant1tatively coprecipitated with CuS in 20 minutes, but in the presence of large amounts of ammonium salts, the reaction 18 somewhat slower. Note (7). Normally, the prec1pitate 18 readily P1lterable through ordinary filter paper, but membrane filters offer better retentivity and speed.

Procedure 6

Source - Q. E. Boyd, Q. V. Larson, J. Phys. Chem. 60, 707 (1956)

Isolation of Long-11ved Tc from Minerals

\section{Introduction}

This procedure was used in a search for long-lived Tc in nature. It should be adaptable to the isolation of technetium from various materials.

\section{Procedure}

The mineral (Mos 2 or yttrotantalite) was fused with the f1ve-fold amount of $\mathrm{Na}_{2} \mathrm{O}_{2}$ in a zirconium or 1ron crucible. Fusions were conducted with $25 \mathrm{~g}$. allquots of ore in iron and with 1-10 B. al1quots in zirconlum crubibles. In nearly all cases $\boldsymbol{\gamma}$-emitting radioactive technetium (usualiy 4.2 d Tc 96 $+60 \mathrm{~d} \mathrm{Tc}^{95 \mathrm{~m}}$ ) was added to the ore to permit the monitoring of the chemical processing at every step. 


\section{Procedure 6 (Continued)}

The fusion mixture was dissolved in water, and the solution brought to bolling and digested to destroy residual peroxide. Upon cooling to room temperatures, ferric hydroxide from Iron originaliy present in the ore and mainly from the corrosion of the iron crucible was then allowed to settle. Separate tests using radio-tracers showed no technetium was lost by coprecipitation with iron hydroxide. After filtering to remove the iron, volumes of solution ranging from 1 to 45 liters were passed through a $9.6 \mathrm{~cm}$. by $22 \mathrm{~cm}$. deep bed of strong-base anton exchanger ( $v 1 z$., Dowex-2 or Amberlite IRA 410) which extracted all of the technetium (as proved by tracers), the rhenlum, and a small part of the molybdate, sulfate or ruthenate, etc., also formed by the oxidizing, alkaIine fusion. Cationic constituents such as $\mathrm{Na}, \mathrm{Cu}, \mathrm{N1}$, etc., passed through the resin bed. Molybdate and other anions were eluted with $1 \mathrm{MNNO}_{3}$ at $\mathrm{pH} 10$ or with $2 \underline{\mathrm{N}} \mathrm{NaOH}$ solution after rinsing the bed with distilled water.

After a second water rinse, both perrhenate and pertechnetate were displaced quantitatively with $2 \underline{\mathrm{N}} \mathrm{NaClO}_{4}$ or $2 \underline{\mathrm{N}}$ $\mathrm{HClO}_{4}$. The eluent solution usually contained approximately 5-10 mg. of rhenium, and microgram or smaller quantities of technetium, although sometimes as much as one gram of rhenium was present. After acidification (if necessary), the eluate was heated, treated with bromine water to oxidize any reduced technetium, and then treated w1th $\mathrm{H}_{2} \mathrm{~S}$ gas to precipltate rhenIum and technetium sulfides. Quantitative coprecipitation of technetium was insured by aigestion at $90^{\circ}$, then the rhenium sulfide was separated by filtering, dissolved with ammonia and hydrogen peroxide and the solution evaporated to near-dryness 


\section{Procedure 6 (Continued)}

on a steam-bath. Th1s residue was taken up in $10 \mathrm{~N} \mathrm{HCl}$, the solution heated for one hour, and rhenium sulfide again prec1pitated with hydrogen sulfide. Technetium is not coprecipitated under these conditions, and remains in the supernatant ac1d solution. After filtration, this supernatant was diluted to a concentration of $I \underline{N}$, heated, treated with bromine water, and then with hydrogen sulfide to precipltate residual fractional milligram quantities of rhenium together with technetium which is again coprecipitated. One or more of these cycles served to give a considerable reduction in the amount of rhenium. Further reduction of the rhenlum content of the technetium fraction was accomplished by use of lon-exchange chromatography using a $0.78 \mathrm{~cm}$. by $30 \mathrm{~cm}$. deep bed of 120-200 mesh strong-base anion exchanger, Dowex-2. The final rhenium sulfide prec1p1tate mentioned above was dissolved in ammoniacal hydrogen peroxide, and the pertechnetate and perrhenate lons in this solution were absorbed on the top of the bed. The chromatograph1c separation was performed using perchlorate solutions as eluents at flow rates averaging less than $0.5 \mathrm{ml} / \mathrm{min}$. Fractions containing the technetium were combined, made $1 \mathrm{~N}$ in $\mathrm{HCl}$, heated and treated with bromine, and then one $\mathrm{mg}$. of copper was preclpitated as copper sulf1de. This "technet1um concentrate" was processed as required by the varlous assay methods: (1) For spectrochemical analysis, it was dissolved in ammonia and hydrogen peroxide and the technetium electroplated on to the ends of 1/4-inch diameter cylindrical copper electrodes after adjustIng the solution to approximate neutrality and adding fluoride Ion to assist the electrodeposition. (2) For spectrophotometric analysis using a Beckman Model DU spectrophotometer, the copper sulfide was dissolved in ammoniacal peroxide, then 


\section{Procedure 6 (Continued)}

copper was removed by passage through a small cation-exchange column (Dowex-50) and finally the solution was evaporated to a volume of one $\mathrm{ml}$. (3) For polarographic analysis the treatment was the same as for (2), except for the omission of the evaporation step. (4) For activation analysis the Cus was carefully wrapped in pure polystyrene foll and irradiated for six hours with neutrons after which it was dissolved in ammonlacal peroxide, treated with a cation exchanger to remove copper and other activated cationic impurities, chromatographed on a small anion-exchange column (Dowex-l) to obtain a pure technetium fraction, and then examined with scintillation spectrometer for the presence of the characteristic $14 \mathrm{Kev}$. $\gamma$-ray of an induced $6.0 \mathrm{~h} \mathrm{Tc} 99 \mathrm{~m}$ activity. (5) For mass spectrometric analysis the CuS was dissolved and copper was removed as before, then the technet1um was electroplated onto 1ridium and finally reduced to its metal in hydrogen gas at about $400^{\circ}$. In all cases above just preceding the assay step the amount of Initially added technetium radio-tracer was determined to permit an estimate for the "over-all" chemical yleld, or recovery for the separation from the starting material. 
Procedure 7

Source - E. Anders

Isolation of Long-IIved Tc from Minerals

\section{Introduction}

Th1s procedure was used in 2 search by neutron act1vation analysis for long-l1ved $\mathrm{TC}^{98}$ in nature. It was primarily desigried for chromite, columb1te, and other non-81licate oxide minerals, but can be adapted to a varlety of materials.

\section{Procedure}

Plfty grams of the finely powdered (-100 mesh) mineral was fused with 100 grams of $\mathrm{NaOH}$ and 40 grams of $\mathrm{Na}_{2} \mathrm{O}_{2}$ for 20-30 min. In a covered n1ckel crucible. More $\mathrm{Ne}_{2} \mathrm{O}_{2}$ was added, If necessary, to ensure the oxidation of $\mathrm{Mn}$ to $\mathrm{MnO}_{4}=$. The melt was poured on a steel plate, cooled, transferred to a beaker, and dissolved with mechanical stirring by addition of $250 \mathrm{~g}$ of 1ce. Care was taken to have an excess of $\mathrm{MnO}_{4}=$ present at all tImes to ensure oxidation of any $\mathrm{TcO}_{2}$ to $\mathrm{TcO}_{4}{ }^{-}$. If required, $\mathrm{KMnO}_{4}$ was added.

The solution was centrifuged, the residue washed twice with $50 \mathrm{ml}$ portions of $\mathrm{H}_{2} \mathrm{O}$, and the combined solutions recentr1ruged. The centrifugate was adjusted to about $1 \mathrm{~F} \mathrm{NaOH}$ by addition of $12 \mathrm{~N} \mathrm{H}_{2} \mathrm{SO}_{4}$, and $\mathrm{Na}_{2} \mathrm{O}_{2}$ was added to reduce $\mathrm{MnO}_{4}=$ to $\mathrm{MnO}_{2}$. The solution was heated to coagulate the precipitate, and filtered. The filtrate was neutralized with $12 \mathrm{~N} \mathrm{H}_{2} \mathrm{SO}_{4}$, and refiltered to remove small amounts of $\mathrm{Zr}, \mathrm{Pb}, \mathrm{Sn}, \mathrm{Mb}, \mathrm{Ta}$, T1, S1, W, and other elements precipitated under these conditions. The acldity was adjusted to $1 \underline{F} \mathrm{H}^{+}, 20 \mathrm{mg}$ of $\mathrm{Cu}^{2+}$ per liter of solution was added, and copper sulfide was preclpitated by bubbling $\mathrm{H}_{2} \mathrm{~S}$ through the hot solution. After a digestion time of 2 hrs., the solution was filtered through a coarse membrane 


\section{Procedure 7 (Continued)}

filter, the precipitate transferred to a $125 \mathrm{ml}$ dist1ling flask, and dissolved in $1-2 \mathrm{ml}$ conc. $\mathrm{HNO}_{3}$. Twenty $\mathrm{ml}$ of conc. $\mathrm{H}_{2} \mathrm{SO}_{4}, 10 \mathrm{ml} 85 \% \mathrm{H}_{3} \mathrm{PO}_{4}$, and $2 \mathrm{~B} \mathrm{Ce}\left(\mathrm{SO}_{4}\right)_{2}$ were added, and the flask connected to a distilling apparatus equipped for steam distillation. The heat was adjusted so as to give a distillation rate of 0.5 to $0.8 \mathrm{ml} / \mathrm{mln}$, and the temperature of the solution measured at frequent intervals. The fraction distiling below $210^{\circ} \mathrm{C}$, contalning nearly all of the excess $\mathrm{HNO}_{3}$, was discarded. Steam was passed through the solution as soon as the temperature had reached $230^{\circ}$, and the distillation continued between 240 and $260^{\circ}$ unt1l 75 to $90 \mathrm{ml}$ had dist1ll.ed over. An aliquot of the distiliate was titrated against $\mathrm{NaOH}$, and the ac1dity adjusted to $1-1.5 \mathrm{~N} \mathrm{H}^{+}$by addition of $\mathrm{H}_{2} \mathrm{SO}_{4}$. Two $\mathrm{mg}$ of $\mathrm{Cu}^{2+}$ carrier ${ }^{*}$ was added, the distillate heated to about $80^{\circ}$ on the steam bath, and the sulfide precipltated as before. The precipitate was filtered through a fritted glass funnel and dissolved in a 5:l mixture of concentrated $\mathrm{NH}_{4}$ OH and $\mathrm{H}_{2} \mathrm{O}_{2}$. Because of the rapid catalytic decomposition of $\mathrm{H}_{2} \mathrm{O}_{2}$ by $\mathrm{Cu}^{2+}$, the solvent was added in 0.05 to $0.1 \mathrm{ml}$ portions, and the solution removed by suction before adding fresh solvent ${ }^{*}$.

The solution $(2-3 \mathrm{ml})$ was heated on the steam bath unt1l most of the $\mathrm{NH}_{3}$ had evaporated ${ }^{* *}$, cooled, and acidified with $6 \mathrm{~N} \mathrm{H}_{2} \mathrm{SO}_{4}$, to give a final acidity of $0.1 \mathrm{~N} \mathrm{H}^{+}$. Th1s solution

\footnotetext{
*Specially purified.

** In the presence of large amounts of rhenlum, some unreacted sulfide usually ran through the filter during the dissolution. In this case, the solution was heated to coagulate the sulilde, and refiltered. $* * *$

The heating ensured the conversion of sulfo-salts to $\mathrm{TCO}_{4}{ }^{-}$. Tracer experiments indicated that if this step is omitted, losses of $\geqslant 30 \%$ can occur due to differences in the chemical behavior of the two species.
} 


\section{Procedure 7 (Continued)}

was heated on the steam bath for 10 minutes*, cooled, and transferred to a Dowex $1-x 8$ (200-400 mesh) anion exchange column of about $18 \mathrm{~cm}$ length, previously converted to the $\mathrm{ClO}_{4}{ }^{-}$-form. The separation was performed according to Procedure 4. The effluent was acidifled with $\mathrm{H}_{2} \mathrm{SO}_{4}$ to give a final acldity of $1 \underline{\mathrm{N}} \mathrm{H}^{+}, 0.5$ to $1 \mathrm{mg} \mathrm{Cu}^{2+}$ was added, and Cus prec1pitated as in the previous step. Another complete anion exchange cycle followed at this point. The sulfide from this cycle was dissolved in $\mathrm{NH}_{3}$ and $\mathrm{H}_{2} \mathrm{O}_{2}$ as before, and separated from $\mathrm{Cu}^{2+}$ by passing the solution through a quartz ion exchange column $\left(0.2 \mathrm{~cm}^{2} \times 8 \mathrm{~cm}\right)$ f1lled with Dowex 50w-x8, 200-400 mesh, ammonium form. The column was rinsed with $2 \mathrm{ml} 2 \mathrm{~N} \mathrm{NH}_{3}$, the combined effluent was reduced in volume, transferred to a quartz vial and evaporated to dryness under vacuum. The vials were then scaled and 1rradiated. After 1rradiation, the samples were processed as in Procedure 5.

*

Th1 a step was needed in order to remove $\mathrm{CO}_{2}$ and No (from $\mathrm{NO}_{2}^{-}$formed by oxidation of $\mathrm{NH}_{3}$ by $\mathrm{H}_{2} \mathrm{O}_{2}$ ). Otherw18e, the gases were ilberated in the anion exchange column, causing channeling and consequently poor separation.

\section{Procedure 8}

Source - E. Jacob1, Helv. Ch1m. Acta 31. 2118 (1948)

Separation of Technetium and Molybdenum

\section{Introduct1on}

Th1s procedure, which 18 adapted from the 1939 paper of Perrier and Segrè, gives only moderate separation factors, but it $1 \mathrm{~s}$ falrly rapid $(40 \mathrm{~min}$.$) and gives good ylelds (70\%).$ Molybdenum is precipitated with 8-hydroxyquinoline, and the 


\section{Procedure 8 (Continued)}

technetium in the filtrate is coprecipitated with copper sulfide.

\section{Procedure}

Prec1pitate molybdenum with 8-hydroxyquinoline from nextral solution, filter, and make the solution $0.6 \underline{M}$ in $\mathrm{HCI}$ (total volume $50 \mathrm{ml}$ ). Add $0.3-2 \mathrm{mg} \mathrm{Cu}{ }^{++}$carrier, heat, pass $\mathrm{H}_{2} \mathrm{~S}$ into the solution for $15 \mathrm{~min}$, f1lter, and wash the precipitate with $\mathrm{H}_{2} \mathrm{~S}$ water.

\section{Procedure 9}

Source - K. T. Batnbridge, M. Coldhaber,

E. Wilson, Phys. Rev. 90,

430 (1953)

Separation of $\mathrm{Tc}^{99 \mathrm{~m}}$ from Mo 99

\section{Introduction}

This procedure involves co-distillation of technetium with perchloric ac1d. Ruthenlum and rhenlum will also dist1ll under these conditions, but molybdenum w1ll not, if sufficlent phosphoric acid is present.

\section{Procedure}

Molybdenum metal is dissolved in a mixture of $\mathrm{HClO}_{4}$ and $\pi_{3} \mathrm{PO}_{4}$. (The phosphor1c ac1d complexes Mo and prevents its distillation.) Technetium is distilled in an air stream at $120-200^{\circ} \mathrm{C}$, and the dist1liate is collected in water or dilute $\mathrm{i}_{2} \mathrm{SO}_{4}$. The fraction distili1ng below $120^{\circ} \mathrm{C}$ may be discarded. The distillate is redistilled in the presence of Mo holdback sarrier, and the $120-200^{\circ} \mathrm{C}$ praction is again collected. The technetium can be recovered from the distillate by electrolysis at pH 5.5 or by sulfide precipitation. 
Procedure 10

\section{Source - J. B. Gerl1t, Proc. Internat. Conf. \\ Peaceful Uses of Atomic Energy, Geneva, $1955,7,145$ (1956)}

\section{Separation of Technetium from Ruthenium,} Rhentum and Molybdenum

\section{Introduction}

Th1s procedure has been reconstructed by the author from a brief statement in Cerlit's paper. It makes use of the fact that nelther $\mathrm{TcO}_{4}^{-}$nor $\mathrm{ReO}_{4}^{-}$extract 1 tho mixtures of halogenated and oxygenated solvents, even though they do extract Into pure oxygenated solvents.

\section{Procedure}

Make solution $5 \underline{N}$ in $\mathrm{NaOH}$ and extract with equal volume of hexone (methyl-1sobutyl ketone). The distribution coefflclents are: $\mathrm{TcO}_{4}^{-}=17$; $\mathrm{ReO}_{4}^{-}=8.2$; $\mathrm{MOO}_{4}{ }^{-}<0.001$; $R u(I V)<0.001$. Wash with $5 \underline{N}$ NaOH as required.

Dlscard aqueous layer and add enough $\mathrm{CHCl}_{3}$ to organic phase (amount not given) to permit quantitative back-extraction of $\mathrm{ReO}_{4}^{-}$and $\mathrm{TCO}_{4}^{-}$into water.

Make solution $2 \mathrm{~N}$ in $\mathrm{H}_{2} \mathrm{SO}_{4}$, reduce Tc with hydrazine to +4 state, and extract $\mathrm{ReO}_{4}{ }^{-}$1nto 180-amyl alcohol. 
Source - V. I. Sp1tsyn, A. F. Kuzina,

Doklady Akad. Nauk SSSR 124

846 (1959)

Isolation of $\mathrm{Tc}^{99}$ from Molybdenum

\section{Introduction}

Th1s procedure is based on the fact that Tc(VII) w11I coprecipltate with $\mathrm{MgNH}_{4} \mathrm{PO}_{4}$, whereas 1ts lower oxidation states w1ll not. It is rather original in several respects, but should probably be tested more fully.

\section{Procedure}

The 1rradiated $\mathrm{MOO}_{3}$ is dissolved in ammonia, and the technetium is coprecipitated with $\mathrm{MgNH}_{4} \mathrm{PO}_{4}$ and $\mathrm{MgHPO}_{4}$. The precipitate is dissolved in $6 \mathrm{~N} \mathrm{HCl}$, and the technetium is reduced to the +4 and +2 ( $\mathrm{s} 1 \mathrm{c}$ ) states by passing $\mathrm{H}_{2} \mathrm{~S}$ into the solution for some time. The solution is then made basic with ammonia, and the resulting $\mathrm{MgNH}_{4} \mathrm{PO}_{4}$ precipitate is discarded. The flitrate is evaporated to dryness and the ammonium chlor1de is sublimed off. (Note 1 ).

The residue cortalning Tc is taken up in $\mathrm{HNO}_{3}$, the $\mathrm{pH}$ is adjusted to 2 , and the solution passed through a cation exchanger (KJ-2). Technetlum, belng in an anionic state, passes through the column.

The solution 18 evaporated to dryness in a quartz boat, and the ammonium nitrate is volatilized at $180^{\circ} \mathrm{C}$. The residue is dissolved in 2-3 drops of ammoniacal hydrogen peroxide, evaporated to dryness, and taken up in $4 \mathrm{ml} 4 \mathrm{M} \mathrm{HCl}$. Technetium heptasulfide is then precipitated from this solution.

(Note 1). This step presumably requires careful temperature control, to prevent losses of TC. 
Source - E. H. Huffman, R. I. Oswalt, I. A. Williams, J. Inorg. Nucl. Chem. 3, 49 (1956)

Separation of Technetium and Molybdenum by Anion Exchange

1. Introduction

Th1s prooedure gives a falrly simple and rap1d 1onexchange separation of technetium and molybdenum, using HCl and $\mathrm{HNO}_{3}$ as elutriants. The method of recovery of technetium from the nitric acid solution 18 not foolproof, however, and may lead to losses.

\section{Procedure}

Molybdenum and technetium in $0.5 \mathrm{ml}$ of $1.0 \mathrm{M}$ hydrochloric ac1d were added to a column of resin (Dowex-1, 250-500 mesh, $\mathrm{Cl}^{-}$form) $3 \mathrm{~mm}$ in diameter and $21 \mathrm{~mm}$ in length. When the levels of 11quid had just reached the top of the resin, elution was continued with $8 \mathrm{ml}$ of $1.0 \mathrm{M}$ hydrochloric ac1d, at the rate of $1 \mathrm{ml}$ in $15 \mathrm{mlnutes,}$ to remove molybdenum. Technetium was then removed from the column with $8 \mathrm{ml}$ of $4.0 \mathrm{M}$ nitric ac1d at the same rate of elution. The total molybdenum recovered in the first $4.0 \mathrm{ml}$ of hydrochloric ac1d was $100 \%$ of the amount used and the recovery of technetium in the first $4.4 \mathrm{ml}$ of nitric ac1d was 98\%. For some reason, 0.1\% of the technetium activ1ty appeared in the first milliliter of hydrochloric ac1d with the molybdenum, but no more appeared in the next $7 \mathrm{ml}$.

The samples were evaporated to dryness on platinum counting plates. 
Procedure 13

Source - John Q. Adams and E. Anders (unpubl1shed) See also N. F. Hall \& D. H. Johns,

JACS 75,5787 (1953)

Separation of Technetium and Molybdenum by Anton Exchange

\section{Introduction}

In strongly basic solution, molybdenum is only weakly held by the resin, e.g., In $3 \underline{M} \mathrm{NaOH}, D=12$ ( $D=$ amt. per $\mathrm{B}$ of dry resin/amt. per $\mathrm{ml}$ of solution). For $\mathrm{TcO}_{4}^{-}, \mathrm{D}$ is on the order of $10^{3}$, so that a clean separation can easily be accomplished.

\section{Procedure}

The basic solution containing $T c$ and Mo in their highest oxidation states is adsorbed on the column (Dowex 1-x8, 200-400 mesh, $\mathrm{OH}^{-}$form), and the molybdenum is eluted with 25-30 free column volumes of $3 \mathrm{M} \mathrm{NaOH}$. The molybdenum peak should appear at about 15 free column volumes. The technetium is then stripped with about 15 column volumes of $I \mathrm{M} \mathrm{HClO}$ or $\mathrm{NH}_{4} \mathrm{ClO}_{4}$. The rirst 3-4 column volumes should not contain any TC and may be discarded. If a separation from Re 1s desired, the elution may instead be carried out w1th $0.1-0.2 \mathrm{M} \mathrm{ClO}_{4}^{-}$- solutions (Procedure 4). 
Procedure 14

Source - J. B. Gerl1t, Proc. Internat. Conf.

Peaceful Uses of Atomic Energy, Geneva, $1955,7,145$ (1956)

Separation of Technetium and Rhenium

\title{
1. Introduction
}

Th1s appears to be one of the fastest procedures for the separation of TC and Re. It is based on the reduction of Tc(VII) to Tc(IV) by strong HCl, and coprecipitation of Tc(IV) by $\mathrm{Fe}(\mathrm{OH})_{3}$.

\section{Procedure}

Dissolve sample in a small volume of conc. HCl and heat to about $75^{\circ} \mathrm{C}$ for one half hour. Add ferric 1on, dilute the solution somewhat, and precipitate Fe(OH) 3 with ammonia. Wash the technetium-containing precipitate thoroughly with a hydrazine sulfate solution, dissolve in a small amount of conc. $\mathrm{HNO}_{3}$ [thereby oxidizing Tc(IV) to $\mathrm{Tc}$ (VII)] and remove the iron by another ammonia precipitation.

\author{
Procedure 15 \\ Source - I. E. Qlendenin, Nat1. Nuclear Energy \\ Ser., Div. IV-9, Paper 259, \\ 1545 (1951)
}

Separation of Technetium from Fission Products

1. Introduction

Th1s procedure involves a sulfuric acid distillation and coprecipitation with tetraphenylarsonium perrhenate. It gives excellent decontamination from Ru and Mo, but several of the steps are tricky, and should be revised. 


\section{Procedure 15 (Continued)}

\section{Procedure}

Step 1. To $5 \mathrm{ml}$ of an active uranyl nitrate sample, add $10 \mathrm{ml}$ of conc. $\mathrm{HBr}$ and evaporate almost to dryness. Repeat the evaporation with $\mathrm{HBr}$ twice.

Step 2. Transfer the residue completely, with a minimum amount of water, to a distillation flask. Add carefully $10 \mathrm{ml}$ of $\mathrm{H}_{2} \mathrm{SO}_{4}$. Heat gently to bolling and distill into a 50-ml centrifuge tube contalning $20 \mathrm{ml}$ of water unt1l less than $2 \mathrm{ml}$ of $\mathrm{H}_{2} \mathrm{SO}_{4}$ remains in the flask (Note 1 ).

Step 3. Add $10 \mathrm{mg}$ of rhenfum carrier to the distillate, heat nearl: to bolling, and saturate with $\mathrm{H}_{2} \mathrm{~S}$ for 5 to 10 min with continued heating. Centrifuge, and discard the supernatant solut1ua.

Step 4. Wash the $\mathrm{Re}_{2} \mathrm{~S}_{7}$ with about $10 \mathrm{ml}$ of $\mathrm{H}_{2} \mathrm{O}$ and dissolve by heatiag with $1 \mathrm{ml}$ of conc. $\mathrm{HNO}_{3}$. Add $5 \mathrm{ml}$ of conc. $\mathrm{HBr}$ and evaporate nearly to dryness. Repeat the evaporation first with $5 \mathrm{ml}$ of $\mathrm{HNO}_{3}$ and then with $5 \mathrm{ml}$ of $\mathrm{HCl}$ (Note 2).

Step 5. Dilute the residue to $20 \mathrm{ml}$ with $\mathrm{H}_{2} \mathrm{O}$, add about $2 \mathrm{mg}$ of Iron carrier, heat, and add $\mathrm{NH}_{4} \mathrm{OH}$ until $\mathrm{Fe}(\mathrm{OH})_{3}$ is just precipitated (Note 3 ).

Step 6. Centr1fuge, and discard the $\mathrm{Fe}(\mathrm{OH})_{3}$ precipitate. Repeat the scavenging by a second addition of about 2 mg of Iron carrier. Centrifuge, and discard the precipitate.

Step 7. Heat, and add I $\mathrm{ml}$ of $0.05 \mathrm{M}\left(\mathrm{C}_{6} \mathrm{H}_{5}\right)_{4} \mathrm{AsCl}$ to precipitate $\left(\mathrm{C}_{6} \mathrm{H}_{5}\right)_{4} \mathrm{AsReO}_{4}$. Wash three times with $5 \mathrm{ml}$ of $\mathrm{H}_{2} \mathrm{O}$, dry at $110^{\circ} \mathrm{C}$ for $10 \mathrm{~min}$, welgh and mount.

(Note 1) If reducing substances are present in the $\mathrm{H}_{2} \mathrm{SO}_{4}$, ylelds will be low. Unfortunately, strong oxidizing agents cannot be added, since they will oxidize $\mathrm{Ru}$ to $\mathrm{RuO}_{4}$, causing it to distill. 
(Note 2) The evaporations with $\mathrm{ENO}_{3}$ arid $\mathrm{HCl}$ are 11 kely to cause losses. It would be better to remove lodine by solvent extraction instead (Procedure 16).

(Note 3) It is imperative that Tc be in 1 ts highest oxidation state in this step, so that it will not carry on $\mathrm{Fe}(\mathrm{OH})_{3}$.

\section{Procedure 16}

Source - S. Tribalat, J. Beydon, Anal. Chim. Acta 8 , 22 (ig53)

Separation of Technetium from Fission Products

\section{Introduction}

This procedure involves extraction of pertechnetate into chloroform in the presence of tetraphenylarsonium ion.

Dissolve $\mathrm{UO}_{3}$ in $\mathrm{H}_{2} \mathrm{SO}_{4}$ containing a few HS of $\mathrm{I}^{-}$noldback. Add $\mathrm{S}_{2} \mathrm{O}_{8}$ "and extract $\mathrm{I}_{2}$ into toluene. Heat solution to bolling to remove traces of $\mathrm{I}_{2}$, neutralize with $\left(\mathrm{NH}_{4}\right)_{2} \mathrm{CO}_{3}$, add more $\mathrm{S}_{2} \mathrm{O}_{8}=$ and heat to bo1ling. Extract $\mathrm{TcO}_{4}^{-}$into $\mathrm{CHCl}_{3}$ at $R=10^{-4} M$. Other fission products do not seem to interfere. The technetium can be recovered from the organ1c phase by back-extraction into $\mathrm{HClO}_{4}$ or $\mathrm{H}_{2} \mathrm{SO}_{4}$ (Procedure 5) or by evaporation to dryness. 
Procedure 17

Source - G.W Parker, U.S. Atomic Energy Comm. Report ORNL-1116 (Jan. 29, 1952), pp. 26-30

Isolation of Tc99 from Mixed F1ssion Products
("Redox" Waste)

\section{Introduction}

This process is designed for large-scale separation of Tc 99 from mixed fission product wastes. It involves coprecipitation with tetraphenylarsonium perchlorate.

\section{Procedure}

To 100 gallons solution contalning $1 \mathrm{~g}$ Tc(VII) 1 s added $17 \mathrm{~g} \mathrm{HClO} 4$ carrier. The solution $1 \mathrm{~s}$ heated, an excess of tetraphenylarsonium chloride is added, and the precipitate 1s filtered after cooling. The mixed perchlorate-pertechnetate precipitate is dissolved in ethyl alcohol, the solution is passed through a strong-base anion exchanger in the chloride form, and the adsorbed pertechnetate eluted with about 10 free column volumes of $2 \mathrm{~N} \mathrm{HClO}_{4}$.

Alternatively, the precipitate can be dissolved in conc. $\mathrm{H}_{2} \mathrm{SO}_{4}$. The technetium can elther be co-distilled with the ac1d, and preclpitated as the sulfide, or separated as the dioxide by electrolysis between bright platinum electrodes. 


\section{REFERENCES}

1. Smlth, W. T., Jr., Cobble, J. W., and Boyd, G. E., J. Am. Chem. Soc., 75, 5773 (1953) and 75, 5777 (1953).

2. Crouthamel, B. C., Anal. Chem., 29, 1756 (1957)

3. Tribalat, S., and Beydon, J., Anal. Ch1m. Acta, 8, 22 (1953).

4. Sen Sarma, R. N., Anders, E., and Miller, J. M., J. Phys. Chem., 63559 (1959).

5. Maun, B. K., and Davidson, N., J. Am. Chem. Soc., 72, 2254 (1950).

6. Frled, S., and Hall, N. F., Chemlstry of Technet1um, presented at Spring Neeting of the American Chemical Soclety, Apr11 1950. See also Phys. Rev., 81, 741 (1951).

7. Frled, S., J. Am. Chem. Soc., 70, 442 (1948).

8. Cobble, J. W., Nelson, C. M., Parker, G. W., Sm1th, W. T., Jr., and Boyd, G. B., J. Am. Chem. Soc., 74, 1852 (1952).

9. Parker, G. W., private communication quoted in Boyd, G. E., J. Chem. Ed., 36, 3 (1959).

10. Parker, G. W., U.S. Atomic Energy Commission Report ORNL-1260 (May 1952).

11. Rulfs, C. L., and NeInke, W. W., J. Am. Chem. Soc., 74, 235 (1952).

12. Wu. C. S. (Personal communication, sept. 1950). 
13. Boyd, G. E., Cobble, J. W., Nelson, C. M., and Smlth, W. T., Jr., J. Am. Chem. Soc., 74, 556 (1952).

14. Parker, G. W., and Mart1n, W. J., U.S. Atomic Energy Commission Document ORNL-1116 (1952)

15. Gerl1t, J. B., Proc. Internat. Conf. Peaceful Uses of Atomlc Energy, Geneva, 1955, Vol. 7, p. 145 (United Nations, New York, Nen York, 1956).

16. Glendenin, I. E., In Radiochemical Studies: The Fission Products, National Nuclear Energy Series, Div. XV-9, Paper 259, p. 1545 (Coryell, C. D., and Sugarman, N., Ed., McGrawH11l Book Co., Inc., New York, New York, 2086 pp., 1951).

17. Parker, G. W., and Martin, W. J., U.S. Atomic Energy Commission Document ORNL-870 (1950).

18. Flegenhelmer, J., and Seelmann-Eggebert, W., Proceedings of the First International Conference on the Peaceful Uses of Atom1c Energy, Geneva, 1955, Vol. 7, p. 152 (Un1ted Nations, New York, New York, 1956).

19. Boyd, G. E., J. Chem. Educ. 36, 3 (1959).

20. Perrier, C., and Segre, E., J. Chem. Phys. 7, 155 (1939).

21. Jacob1, E., Helv. Ch1m. Acta, 31, 2118 (1948).

22. Flagg, J. F., and Ble1dner, W. E., J. Chem. Phys., 13, 269 (1945).

23. Boyd, G. E., Larson, Q. V., and Motta, E. E., J. Am. Chem. Soc. 82,809 (1960).

24. Gellmann, W., and Lange, F., Z. anal. Chem., 126, 321 (1943).

25. Ge1lmann, W., Wlechmann, F., and Wrigge, F. W., Z. anal. Chem., 126, 418 (1943).

26. Gellmann, W., and Bode, H., z. anal. Chem., 130, 222 (1950).

27. Morgan, F., and Sizeland, M. L., United Kingdom Atomic Energy Authority Report AERE C/M 96 (1950).

28. Anders, E., unpublished data. 
29. Perrier, C., and segre, E., J. Chem. Phys., 5, 712 (1937).

30. Rogers, I. B., J. Am. Chem. Soc., 71, 1507 (1949).

31. Nelson, C. M., Boyd, O. E., and Smith, W. T., Jr., J.Am. Chem. Soc., 76, 348 (1954).

32. de Carvalho, R. A. Q., Proc. Second U.N. International Conf. on the Peaceful Uses of Atomic Energy, Geneva, 1958, Paper \#1810.

33. Alperovitch, E., Contribution to the Problem or Naturally Occurring Technet1um (Doctoral Dissertation, Columbia University, New York, New York, January 1954).

34. Busey, R. H., U.S. Atom1c Energy Comm1ssion, Document CRNL2782 (1959).

35. Thomason, P. F., U.S. Atomic Energy Commission Document ORNL-2453 (1958).

36. Boyd, Q. B., Larson, Q. V., and Motta, E. B., U.S. Atom1c Energy Commission Document AECD-2151 (1948).

37. Herr, W., Z. Naturforsch., 9A, 907 (1954).

38. Parker, G.W., Reed, J., and Ruch, J.W., U.S. Atomic Energy Commission Document ABCD-2043 (1948).

39. Mhelich, J. W., Qoldhaber, M., and W1lson, B., Phys. Rev., 82, 972 (1951).

40. Bainbridge, K. T., Goldhaber, M., and W1lson, E., Phys. Rev., 90, 430 (1953).

41. Sugarman, N., and Richter, H., Phys. Rev., 73, 1411 (1948).

42. G1le, J. D., Garrison, W. M., and Hamilton, J. G., U.S. Atomic Energy Commission Document UCRL-1419 (1951).

43. Go1sh1, W., and Libby, W. F., J. Am. Chem. Soc., 74, 6109 (1952).

44. Johns, D. H., Tracer Studies on Technetium Separations (Doctoral Dissertation, University of Wisconsin, Madison, W1scons1n, 1954). 
45. Boyd, G. E., and Larson, Q. V., U.S. Atomic Energy Comm. Documents ORNL-2159 (1956) and ORNL-2584 (1958).

46. Boyd, G. E., and Larson, Q. V., J. Phys. Chem., Vol. 64, 988 (1960).

47. Kraus, K. A., and Nelson, F., Proceedings of the First International Conference on the Peaceful Uses of Atomic Energy, Geneva, 1955, Vol. 7, p. 113 (United Nations, New York, New York, 1956).

48. Huffman, E. H., Oswalt, R. L., and Wlll1ams, L. A., J. Inorg. Nucl. Chem., 3, 49 (1956)

49. Atteberry, R. W., and Boyd, G E., J. Am. Chem. Soc., 72, 4805 (1950)

50. Hall, N. F., and Johns, D. H., J. Am. Chem. Soc., 75, 5787 (1953).

51. Alperovitch, E., and Miller, J. M.,. Nature, 176, 299 (1955).

52. Boyd, Q. E., and Larson, Q. V., J. Phys. Chem., 60, 707 (1956)

53. Glueckauf, E., In Ion Exchange and 1ts Applicat1ons, p. 40, (Soc. Chem. Industry, London, 1955).

54. F1sher, S. A., and Meloche, V. W., Anal. Chem., 24, 1100 (1952)

55. Kraus, K. A., Nelson, Q. F., and Moore, G. E., J. Am. Chem. Soc., 77, 3972 (1955).

56. Lederer, M., Anal. Ch1m. Acta, 12, 146 (1955).

57. Lev1, M., and Lederer, M., J. Inorg. Nucl. Chem., 4, 381 (1957).

58. Anders, E., Phys. Rev. 110, 427 (1958). 


\title{
NUCLEAR SCIENCE SERIES: MONOGRAPHS ON RADIOCHEMISTRY, RADIOCHEMICAL TECHNIQUES, AND NUCLEAR MEDICINE
}

\author{
Aveileble from the Nationed Technicel Informotion Service. \\ U. S. Depertment of Commerce, Springfiedd, Virginia 22161
}

\section{ELEMENTS}

Ahummum and Gallum, NAS-NS-3032 [1961], $\$ 925$

Amercium and Cunum, NAS-NS-3006 [1960]. $\$ 975$

Antmony. NAS-NS-3033 [1961], $\$ 950$

Arsenic, NAS-NS-3002 (Rev) [ 1965], \$9 25

Astatine, NAS-NS-3012 [1960], $\$ 900$

Barum, Calcaum, and Strontum, NAS-NS3010 [1960], $\$ 1100$

Beryium, NAS-NS-3013 [1960]. \$9 60

Busmuth, NAS-NS-3061 [1977], $\$ 1175$

Cadmum, NAS-NS-3001 [1960], \$950

Cation. Nitrogen, and Oxygen, NAS-NS. $3019[1960], \$ 875$

Cesum, NAS-NS-3035 [1981], $\$ 975$

Chromum. NAS-NS-3007 (Rev) [1964], $\$ 975$

Cobelt. NAS-NS-3041 [1961], 51050

Copper, NAS-NS-3027 [1961], $\$ 950$

Fhome. Chlonne. Bromme, and lodine, NAS-NS-3005 [1960], \$9 25

Francum, NAS-NS-3003 [1960], $\$ 900$

Germanum, NAS-NS-3043 [1961]. \$9 25

Gold. NAS-NS-3036 [1961], $\$ 900$

Indum, NAS-NS-3014 [1960], \$9 25

lodine. NAS-NS-3062 [1977] $\$ 1075$

Indum, NAS-NS-3045 [1961], \$900

lron. NAS-NS-3017 [1960], 5925

Lead, NAS-NS-3040 [1961], $\$ 1200$

Magnesum, NAS-NS-3024 [1981], $\$ 875$

Manganese. NAS-NS-3018 (Rev) [1971]. 5975

Mercury. NAS-NS-3026 (Rev) [1970], \$13 25

Molybdenum, NAS-NS-3009 [1960], $\$ 900$

Neptunum, NAS-NS-3060 [1974], \$1375

Nickel, NAS-NS-3051 [1961], \$9 50

Nobum and Tentalum, NAS-NS-3039 [1961], $\$ 950$

Osmum, NAS-NS-3046 [1961], $\$ 875$

Palladum, NAS-NS-3052 [1961], \$975

Phosphorus, NAS-NS-3056 [1962], \$9 00

Platumum, NAS-NS-3044 [1961], \$9 00

Phutonum, NAS-NS-3058 [1965], \$12 75

Polonum, NAS-NS-3037 [1961], $\$ 975$

Potassium, NAS-NS-3048 [1961], $\$ 925$

Protactinmm, NAS-NS-3016 [1959], \$10 25

Radum, NAS-NS-3057 [1964], \$13 25

Rare Earths-Scandum, Yttnum, and Actunum, NAS-NS-3020 [1961]. \$15 25

Rare Gases, NAS-NS-3025 [1960]. $\$ 950$

Recent Redwochemical Separation Procedures for As, At, Be, Mg. N, Ru, and Se, NAS-NS3059 [1974], $\$ 1025$

Rhenum, NAS-NS-3028 [1961], $\$ 925$

Phodum. NAS-NS-3008 (Rev) [ 1965], $\$ 1000$

Rubidum, NAS-NS-3053 [1962], $\$ 900$

Ruthenum, NAS-NS-3029 [1961], \$10 25

Selenmm, NAS-NS-3030 (Rev) [1965], $\$ 950$

Simcon. NAS-NS-3049 (Rev) [ 1968], \$10 00

Siver, NAS-NS-3047 [1961], $\$ 950$

Sodum, NAS-NS-3055 [1962], $\$ 925$

Sulfur, NAS-NS-3054 [1962], \$900

Technetuum, NAS-NS-3021 [1960]. \$950
Telumum, NAS-NS-3038 [ 1961]. \$9 25

Thonum. NAS-NS-3004 [1960]. $\$ 1000$

Tin, NAS-NS-3023 [1960]. $\$ 1000$

Titenum, NAS-NS-3034 (Rov) [1971], \$10 50

Trenscumum Elements, NAS-NS-3031 [1960], $\$ 900$

Tungsten. NAS-NS-3042 [1961], $\$ 925$

Urenum. NAS-NS-3050 [1961], \$1700

Venadum, NAS-NS-3022 [1960], $\$ 1000$

Zinc, NAS-NS-3015 [1960], $\$ 960$

Zirconum and Hafnum. NAS-NS-3011 [1960], $\$ 950$

\section{TECHNDOUES}

Absolute Measurement of Aphe Emssion and Sponteneous Fission, NAS-NS-3112 [1968]. $\$ 950$

Activation Anelyses with Charged Particles. NAS-NS-3110 [1966], \$9 25

Application of Distilation Tectinques to Radochemucal Seperations, NAS-NS-3108 [1962], $\$ 900$

Applications of Computers to Nucleer and Radochemistry. NAS-NS-3107 [1962], \$16 00

Cation-Exchange Technques in Radiochemustry. NAS-NS-3113 [ 1971], $\$ 1300$

Chemcal Yield Determmotions in Radiochemistry. NAS-NS-3111 [1967]. \$10 50

Detection and Maesurement of Nucleer Radiation. NAS-NS-3105 [1962], $\$ 1175$

Lquid-Laqud Extrection with HighMoleculer-Weght Amnes, NAS-NS-3101 [1960], \$10 25

Low-Level Radiochemcal Seperations. NAS-NS-3103 [1961], $\$ 900$

Neutron Activation Techniques for the Meesure ment of Trace Metats in Envronmental Semples, NAS-NS-3114 [1974]. \$1000

Peper Chromatogrephic and Electromigration Technques in Radiochemustry, NAS-NS3106 [ 1962]. $\$ 925$

Proceseng of Countung Data, NAS-NS-3109 [1966], \$12 25

Repid Radochemical Seperations. NAS-NS3104 [1961], \$1125

Separations by Solvent Extraction with Tn-n-octyphosphine Oxade. NAS-NS-3102 [1961]. $\$ 950$

Users' Gudes for Redroectuvty Standards. NAS-NS-3115 [1974]. \$10 25

\section{NUCLEAR MEDICINE}

The Synthesis of Cerbon-11. Fuorne-18. and Nitrogen-13 Lebeled Radiotracers for Bromedical Applications, NASNS-3201 [1982], $\$ 1125$

Redionuchide Generators for Bromedical Applucations, NAS-NS-3202/JAA. R D Finn, V J Molinska, H B Hupf, and $H$ Kramer (1983), $\$ 1225$ 